\title{
Nanoneedle-forest NiCo204@nitrogen-doped Carbon-Mo2C/CC as Double Functional Electrocatalysts for Water Hydrolysis and Zn-air Batteries
}

\section{Changhua Xu}

The Youth Innovation Team of Shaanxi Universities, Shaanxi Key Laboratory of Photoelectric Functional Materials and Devices, School of Materials and Chemical Engineering, Xi'an Technological University, Xi'an 710021, People's Republic of China

Qiguan Wang ( $\sim$ qiguanwang@163.com )

The Youth Innovation Team of Shaanxi Universities, Shaanxi Key Laboratory of Photoelectric Functional Materials and Devices, School of Materials and Chemical Engineering, Xi'an Technological University, Xi'an 710021, People's Republic of China

\section{Shaoting Zhao}

The Youth Innovation Team of Shaanxi Universities, Shaanxi Key Laboratory of Photoelectric Functional Materials and Devices, School of Materials and Chemical Engineering, Xi'an Technological University, Xi'an 710021, People's Republic of China

\section{Sumin Wang}

The Youth Innovation Team of Shaanxi Universities, Shaanxi Key Laboratory of Photoelectric Functional Materials and Devices, School of Materials and Chemical Engineering, Xi'an Technological University, Xi'an 710021, People's Republic of China

\section{Research Article}

Keywords: Multifunctional Electrocatalysts, NiCo204, Nitrogen-Doped Carbon-Mo2C, Water Hydrolysis, Zn-air batteries

Posted Date: May 20th, 2021

DOI: https://doi.org/10.21203/rs.3.rs-533316/v1

License: (c) (1) This work is licensed under a Creative Commons Attribution 4.0 International License. Read Full License 


\title{
Nanoneedle-forest $\mathrm{NiCo}_{2} \mathrm{O}_{4} @$ nitrogen-doped Carbon-Mon $\mathrm{C} / \mathrm{CC}$ as Double Functional Electrocatalysts for Water Hydrolysis and Zn-Air Batteries
}

\author{
Changhua Xu, Qiguan Wang,* Shaoting Zhao \& Sumin Wang* \\ The Youth Innovation Team of Shaanxi Universities, Shaanxi Key Laboratory of Photoelectric \\ Functional Materials and Devices, School of Materials and Chemical Engineering, Xi'an \\ Technological University, Xi'an 710021, People's Republic of China
}

\begin{abstract}
The construction of efficient and stable non-precious metal electrocatalysts for water hydrolysis and metal-air batteries is a key to tackle the energy shortage and environmental pollution. Herein, a composite consisting of needle-forest nickel cobalt oxide and nitrogen-doped carbon (NDC)-molybdenum carbide loaded on carbon cloth $\left(\mathrm{NiCo}_{2} \mathrm{O}_{4} @ \mathrm{NDC}-\mathrm{Mo}_{2} \mathrm{C} / \mathrm{CC}\right)$ is synthesized from the hydrothermal method. The introduction of nitrogen-doped carbon and carbon cloth improves the electrical conductivity of the composite, the existence of $\mathrm{NDC}-\mathrm{Mo}_{2} \mathrm{C}$ on $\mathrm{CC}$ makes $\mathrm{NiCo}_{2} \mathrm{O}_{4}$ produce generous oxygen vacancies. Therefore, $\mathrm{NiCo}_{2} \mathrm{O}_{4} @ \mathrm{NDC}-\mathrm{Mo}_{2} \mathrm{C} / \mathrm{CC}$ shows the low overpotentials of HER (120 mV) and OER (220 mV) @10 mA cm${ }^{-2}$ and excellent performances for overall water electrolysis in alkaline medium. Also, $\mathrm{NiCo}_{2} \mathrm{O}_{4} @ \mathrm{NDC}-\mathrm{Mo}_{2} \mathrm{C} / \mathrm{CC}$ exhibits robust oxygen reduction reaction (ORR) performance and a large specific capacity of $778 \mathrm{mAh} \mathrm{g}^{-1}$ and energy density of 104

\footnotetext{
* Corresponding author.

E-mail address: qiguanwang@163.com; suminwang@163.com (S.M. Wang). 
$\mathrm{mW} \mathrm{cm}{ }^{-2}$ as air cathode in $\mathrm{Zn}$-air batteries. This work enriches knowledge to explore multifunctional electrocatalysts to replace noble metallic catalysts.

Keywords: $\quad$ Multifunctional Electrocatalysts, $\mathrm{NiCo}_{2} \mathrm{O}_{4}, \quad$ Nitrogen-Doped Carbon- $\mathrm{Mo}_{2} \mathrm{C}$, Water Hydrolysis, Zn-air batteries

\section{Introduction}

Water splitting devices, fuel cells, and rechargeable metal-air batteries have been regarded as the promising ways to solve energy shortage and environmental pollution [1,2]. However, exploiting high-active and efficient electrocatalysts with low overpotentials in hydrogen evolution reaction (HER), oxygen evolution reaction (OER) and oxygen reduction reaction (ORR) is still a big challenge [3]. Currently, platinum $(\mathrm{Pt})$, palladium $(\mathrm{Pd})$, ruthenium oxide $\left(\mathrm{RuO}_{2}\right)$ and iridium dioxide $\left(\mathrm{IrO}_{2}\right)$ based noble metallic catalysts have been commercially used as the ideal electrocatalysts for HER, OER and ORR due to their low overpotential. However, limited by the high cost and low abundance, they have not yet been widely applied in industrial applications [4,5].

So far, many efforts have been devoted to the construction of inexpensive electrocatalysts, for example, cobalt-phosphate [6], perovskite oxides [7] and 3d transition metal derived hydroxides for OER [8], and transition metal dichalcogenides [9], nitrides [10], phosphides [11,12] and oxides [13,14] for HER. Notably, most of the as-synthesized electrocatalysts possess high activity for only single reaction in one electrolyte. In the case two groups of catalysts need being coupled, the incompatible cooperation generally causes reduction in the water 
hydrolysis efficiency $[15,16]$. In addition, active ORR catalysts usually show poor OER performances and vice versa. Therefore, design of multifunctional catalysts possessing high activity towards HER, OER and ORR are highly necessary [17].

The $\mathrm{Co}_{3} \mathrm{O}_{4}$ [18] and Co-based transition metal oxides [19] have attracted considerable attention and are investigated as a group of high-performance OER electrocatalyst because of their high electrochemical activity, rich oxidation state as well as good durability. Among them, $\mathrm{NiCo}_{2} \mathrm{O}_{4}$ has drawn much research interest [20,21], since the Ni ion partially replaces the octahedral position of trivalent Co ion in spinel structure, which improves the electric conductivity and promotes OER kinetics. Recently, due to the multiple-step redox transformation $\left(\mathrm{Co}^{3+} / \mathrm{Co}^{2+}, \mathrm{Ni}^{3+} / \mathrm{Ni}^{2+}\right)$ researchers found that $\mathrm{NiCo}_{2} \mathrm{O}_{4}$ exhibit high catalytic activity for ORR [22]. Xiao et al. [23] prepared $\mathrm{NiCo}_{2} \mathrm{O}_{4} / \mathrm{CNTs}$ which exhibits a superior OER and ORR catalytic activity.

The intrinsic activity and the quantity of active sites are regarded as two crucial factors affecting catalytic activity [24], which can be improved by regulating the chemical composition, physical size, micro-scale morphology and the overall crystallinity of electrocatalysts. Among them, increase of the surface area of electrocatalyst by designing three-dimensional (3D) nanostructure has been an efficient and simply way to enhance the number of active sites for improvement of electrochemical activities [25].

In this paper, in order to form $3 \mathrm{D} \mathrm{NiCo}_{2} \mathrm{O}_{4}$ nano-structure and increase the surface area, a conductive carbon cloth (CC) was used as the support for growth of $\mathrm{NiCo}_{2} \mathrm{O}_{4}$ 
nanocatalyst. Meanwhile, to enhance the HER catalytic performance of $\mathrm{NiCo}_{2} \mathrm{O}_{4}$, the $\mathrm{CC}$ was pre-coated by a layer of molybdenum carbide $\left(\mathrm{Mo}_{2} \mathrm{C}\right)[26,27]$. Of note, the $\mathrm{Mo}_{2} \mathrm{C}$ easily tends to disproportionate growth and aggregation during synthesis, which generally greatly weakens its catalytic activity. Thus, the $\mathrm{Mo}_{2} \mathrm{C}$ was composited with polyaniline (PANI) nanofibers before in-situ anchored on CC. Under calcination of the $\mathrm{NiCo}_{2} \mathrm{O}_{4} @ \mathrm{PANI}-\mathrm{Mo}_{2} \mathrm{C} / \mathrm{CC}$-based electrode at high temperature, PANI was decomposed into nitrogen-doped carbon (NDC), and the $\mathrm{NiCo}_{2} \mathrm{O}_{4} @$ nitrogen-doped carbon- $\mathrm{Mo}_{2} \mathrm{C} / \mathrm{CC}\left(\mathrm{NiCo}_{2} \mathrm{O}_{4} @ \mathrm{NDC}-\mathrm{Mo}_{2} \mathrm{C} / \mathrm{CC}\right)$ catalyst was finally obtained. The coating of NDC- $\mathrm{Mo}_{2} \mathrm{C}$ between $\mathrm{CC}$ and $\mathrm{NiCo}_{2} \mathrm{O}_{4}$ makes $\mathrm{NiCo}_{2} \mathrm{O}_{4}$ nanoneedles grow thinner, resulting in more oxygen vacancies formed in the nanoneedle-forest $\mathrm{NiCo}_{2} \mathrm{O}_{4}$. The electric conductivity of $\mathrm{Mo}_{2} \mathrm{C}$ is also enhanced by compositing with NDC, which significantly promote the OER and HER catalysis of the system under the cooperation of $\mathrm{NiCo}_{2} \mathrm{O}_{4}$ and $\mathrm{NDC}-\mathrm{Mo}_{2} \mathrm{C}$. In addition, the as-prepared catalyst shows obvious ORR performance capable of being used in both water hydrolysis and Zn-air batteries (Scheme 1).

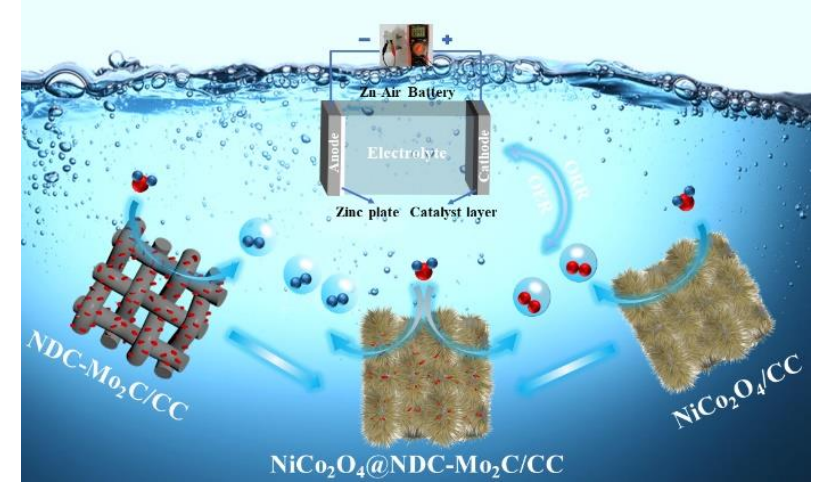

Scheme 1 Schematic illustration of nanoneedle-forest $\mathrm{NiCo}_{2} \mathrm{O}_{4} @ \mathrm{NDC}-\mathrm{Mo}_{2} \mathrm{C} / \mathrm{CC}$ for water hydrolysis and Zn-air batteries. 


\section{Experimental Section}

\subsection{Preparation of PANI}

Polyaniline was prepared by water/organic interface method. Firstly, aniline is distilled under vacuum. Then, $0.1 \mathrm{ml}$ of aniline was cast in $30 \mathrm{ml}$ of toluene solvent, and the solution A was obtained by stirring vigorously for 2 hours at room temperature. Afterwards, take a beaker containing $30 \mathrm{ml}$ of $1.0 \mathrm{M} \mathrm{HCl}$ solution, and add $0.25 \mathrm{mmol}(0.05705 \mathrm{~g})$ of ammonium persulfate to it. Stirred for 10 minutes, then an inorganic phase of solution B was obtained. Mixing of solution A and B in a 100 $\mathrm{ml}$ beaker gives rise to formation of an interface system, which was reacted for 24 hours at $5{ }^{\circ} \mathrm{C}$. The created precipitates are filtered and washed several times by deionized water, methanol and toluene, and then dried in a vacuum oven at $50{ }^{\circ} \mathrm{C}$ for 48 hours. The as-obtained PANI product shows nanofiber morphology observed by SEM image (Fig. S5a), and the diameter is around $55 \mathrm{~nm}$ confirmed by TEM image shown in Fig. S5b.

\subsection{Synthesis of NDC-Mo $\mathrm{Mo}_{2} \mathrm{C} / \mathrm{CC}$}

Typically, $3 \mathrm{mmol}$ of $\left(\mathrm{NH}_{4}\right)_{6} \mathrm{Mo}_{7} \mathrm{O}_{24} \cdot 4 \mathrm{H}_{2} \mathrm{O}$ was dissolved in $35 \mathrm{ml}$ of distilled water and then 1.76 gram of polyaniline was added under magnetic stirring for 5 minutes. Meanwhile, $4.494 \mathrm{mmol}$ of $\mathrm{C}_{16} \mathrm{H}_{33}\left(\mathrm{CH}_{3}\right)_{3} \mathrm{NBr}$ was dissolved in $180 \mathrm{ml}$ distilled water. After 10 minutes the above two solutions were mixed by stirring and then put aside for 12 hours at room temperature. Afterwards, the viscous emulsion at the bottom was transferred to a $50 \mathrm{ml}$ autoclave. At the same time, a piece of cleaned $4 \mathrm{~cm} \times 5 \mathrm{~cm}$ carbon cloth was immersed into the solution and maintained at $200{ }^{\circ} \mathrm{C}$ 
for 12 hours. The obtained $\mathrm{PANI} / \mathrm{Mo}_{2} \mathrm{C} / \mathrm{CC}$ was washed with distilled water and dried at $50{ }^{\circ} \mathrm{C}$ for 2 days. Then, the dry PANI/Mo ${ }_{2} \mathrm{C} / \mathrm{CC}$ was placed into a tube furnace, annealed at $1000{ }^{\circ} \mathrm{C}$ for 6 hours in $\mathrm{N}_{2}$. In the high temperature calcination, the PANI was decomposed to nitrogen-doped carbon (NDC) segments, which were composited on the lattice of $\mathrm{Mo}_{2} \mathrm{C}$. After cooled naturally, NDC-Mo $2 \mathrm{C} / \mathrm{CC}$ composites were obtained.

\subsection{Synthesis of $\mathrm{NiCo}_{2} \mathrm{O}_{4} @ \mathrm{NDC}-\mathrm{Mo}_{2} \mathrm{C} / \mathrm{CC}$}

In a typical preparation of $\mathrm{NiCo}_{2} \mathrm{O}_{4} @ \mathrm{NDC}-\mathrm{Mo}_{2} \mathrm{C} / \mathrm{CC}, 3 \mathrm{mmol} \mathrm{Ni}\left(\mathrm{NO}_{3}\right)_{2} \cdot 6 \mathrm{H}_{2} \mathrm{O}$, $6 \mathrm{mmol} \mathrm{Co}\left(\mathrm{NO}_{3}\right)_{2} \cdot 6 \mathrm{H}_{2} \mathrm{O}$ and $9 \mathrm{mmol} \mathrm{CON}_{2} \mathrm{H}_{4}$ were added in $50 \mathrm{ml}$ distilled water. Then, the mixture was placed in a Teflon-lined autoclave $(100 \mathrm{ml})$ in which a sheet of NDC- $\mathrm{Mo}_{2} \mathrm{C} / \mathrm{CC}$ was immersed, and then reacted at $120{ }^{\circ} \mathrm{C}$ for 2 hours. After cooled to room temperature, the $\mathrm{NiCo}_{2} \mathrm{O}_{4} @ \mathrm{NDC}-\mathrm{Mo}_{2} \mathrm{C} / \mathrm{CC}$ sheet was taken out and washed by using ethanol and distilled water. Upon drying at $60{ }^{\circ} \mathrm{C}$ for 24 hours, the $\mathrm{NiCo}_{2} \mathrm{O}_{4} @ \mathrm{NDC}-\mathrm{Mo}_{2} \mathrm{C} / \mathrm{CC}$ was annealed at $600{ }^{\circ} \mathrm{C}$ in $\mathrm{N}_{2}$ atmosphere for 3 hours, and then cooled naturally. For comparison, the $\mathrm{NiCo}_{2} \mathrm{O}_{4} / \mathrm{CC}$ and $\mathrm{NDC}-\mathrm{Mo}_{2} \mathrm{C} / \mathrm{CC}$ composites were also synthesized according to a similar procedure.

\subsection{Material characterization}

Surface morphology of the samples was monitored by using a JEOL S4800 scanning electron microscope (SEM) equipped with an energy dispersive X-ray spectroscopy (EDX) detector operated at $200 \mathrm{kV}$. The transmission electron microscope (TEM) images were obtained on a JEM-2100 plus machine. The crystallinity was examined by using X-ray diffraction (XRD) on a Rigaku 
D/MAX-2400 powder diffractometer employing nickel-filtered copper radiation $(\mathrm{Cu}$ $\mathrm{K} \alpha, \lambda=1.5406 \AA$ ) as a monochromatic detector in a $2 \theta$ range of $10-80^{\circ}$. Raman measurements were carried out on an ALMEGA Dispersive Raman spectrometer equipped with a laser emitting at $532 \mathrm{~nm}$. X-ray photoelectron spectroscopy (XPS) was performed on a VG ESCALAB 250 spectrometer with an Al Ka X-ray source (1486.6 eV). All binding energies were calibrated based on C 1s signal for carbon at $284.5 \mathrm{eV}$. The electrochemical analysis was conducted employing a CHI660E workstation (Shanghai Chenhua). Electrochemical impendence spectroscopy (EIS) of the samples was investigated in the frequency range from $100000 \mathrm{~Hz}$ to $0.1 \mathrm{~Hz}$ at open circuit potential with an AC perturbation of $5 \mathrm{mV}$. The electrical conductivity of the samples was measured by using the standard four-probe approach at room temperature. Five measurements were generally carried out for each sample to supply the averaged value. The surface area of samples was detected by a Micromeritics TriStar 3020 machine.

\subsection{Electrochemical measurement}

In this paper, the electrochemical properties of the as-prepared $\mathrm{NiCo}_{2} \mathrm{O}_{4} @ \mathrm{NDC}-\mathrm{Mo}_{2} \mathrm{C} / \mathrm{CC}$ were tested by the typical three-electrode method on an electrochemical workstation. The $\mathrm{Hg} / \mathrm{HgO}$ electrode was employed as reference electrode, carbon rod as counter electrode, and $1.0 \mathrm{M} \mathrm{KOH}$ solution was used as the electrolyte. All the detected potentials were calibrated according to the reversible hydrogen electrode (RHE) based on Nernst equation by using the following equation [Eq. (1)]: 
$E_{R H E}=E_{H g / H g O}+0.059 p H+E^{0}{ }_{H g / H g O}$

The as-prepared $\mathrm{NiCo}_{2} \mathrm{O}_{4} @ \mathrm{NDC}-\mathrm{Mo}_{2} \mathrm{C} / \mathrm{CC}$ samples served as the working electrode. To benchmark the obtained results, the weight loading of commercial 20 wt $\% \mathrm{Pt} / \mathrm{C}$ or $\mathrm{IrO}_{2}$ is $2.5 \mathrm{mg} \mathrm{cm}{ }^{-2}$ on glass carbon electrodes. For overall water electrolysis, a two-electrode configuration based on the $2 \mathrm{H}$ type electrolyzer (50 ml) was constructed, with Nafion117 used as the separator. The synthesized catalysts were employed as anode (working electrode) and cathode (counter and reference) electrodes spaced by $5 \mathrm{~cm}$. The ORR activity of $\mathrm{NiCo}_{2} \mathrm{O}_{4} @ \mathrm{NDC}-\mathrm{Mo}_{2} \mathrm{C} / \mathrm{CC}$ was evaluated by rotating disk electrode (RDE). To prepare the ink, $\mathrm{NiCo}_{2} \mathrm{O}_{4} @ \mathrm{NDC}-\mathrm{Mo}_{2} \mathrm{C} / \mathrm{CC}$ was firstly cut into small pieces and ground to be fine powders. The LSV polarization curves for ORR were obtained at $1600 \mathrm{rpm}$. For Zn-air battery, a Zn plate, $6 \mathrm{M} \mathrm{KOH}$ containing $0.2 \mathrm{M} \mathrm{Zn}(\mathrm{Ac})_{2}$ and $\mathrm{NiCo}_{2} \mathrm{O}_{4} @ \mathrm{NDC}-\mathrm{Mo}_{2} \mathrm{C} / \mathrm{CC}$ were used for the anode, electrolyte and the air electrode, respectively. Battery testing and cycling experiments were performed on CT3008W battery testing system (Neware, China).

\section{Results and Discussion}

X-ray diffraction (XRD) experiment was carried out to find the crystalline character of the prepared electrocatalysts, as shown in Fig. 1a. From Fig. 1a, the broad feature at around $2 \theta=26^{\circ}$ corresponds to the c-characteristic peak [28] of the pure carbon cloth. After coated by $\mathrm{NDC}-\mathrm{Mo}_{2} \mathrm{C}$, the $\mathrm{NDC}-\mathrm{Mo}_{2} \mathrm{C} / \mathrm{CC}$ shows the characteristic peaks at $2 \theta=34.4^{\circ}, 38.2^{\circ}, 39.4^{\circ}, 52.2^{\circ}, 61.8^{\circ}, 69.8^{\circ}, 72.5^{\circ}, 74.8^{\circ}$ and $75.8^{\circ}$, attributed to (100), (002), (101), (102), (110), (103), (200), (112) and (201) 
crystal faces of $\mathrm{Mo}_{2} \mathrm{C}$ (JCPDS NO. 35-0787) [29,30], respectively. For the $\mathrm{NiCo}_{2} \mathrm{O}_{4} / \mathrm{CC}$, besides the broad peak of $\mathrm{CC}$ at $2 \theta=26^{\circ}$, the other five diffraction peaks at $2 \theta=31.3^{\circ}, 36.8^{\circ}, 44.6^{\circ}, 59.3^{\circ}$ and $65.0^{\circ}$ are seen [31], which can be indexed as the (220), (311), (400), (511) and (440) lattice planes of the $\mathrm{NiCo}_{2} \mathrm{O}_{4}$ (JCPDS No.73-1702). The XRD patterns of $\mathrm{NiCo}_{2} \mathrm{O}_{4} @ \mathrm{NDC}-\mathrm{Mo}_{2} \mathrm{C} / \mathrm{CC}$ discerned from Fig. 1a contain the characteristic diffraction peaks coupled by those of carbon cloth, $\mathrm{NiCo}_{2} \mathrm{O}_{4}$ and $\mathrm{NDC}-\mathrm{Mo}_{2} \mathrm{C}$, with the position and shape unchanged. This indicates the $\mathrm{NiCo}_{2} \mathrm{O}_{4}$ and $\mathrm{NDC}-\mathrm{Mo}_{2} \mathrm{C}$ were well composited on CC sheets.
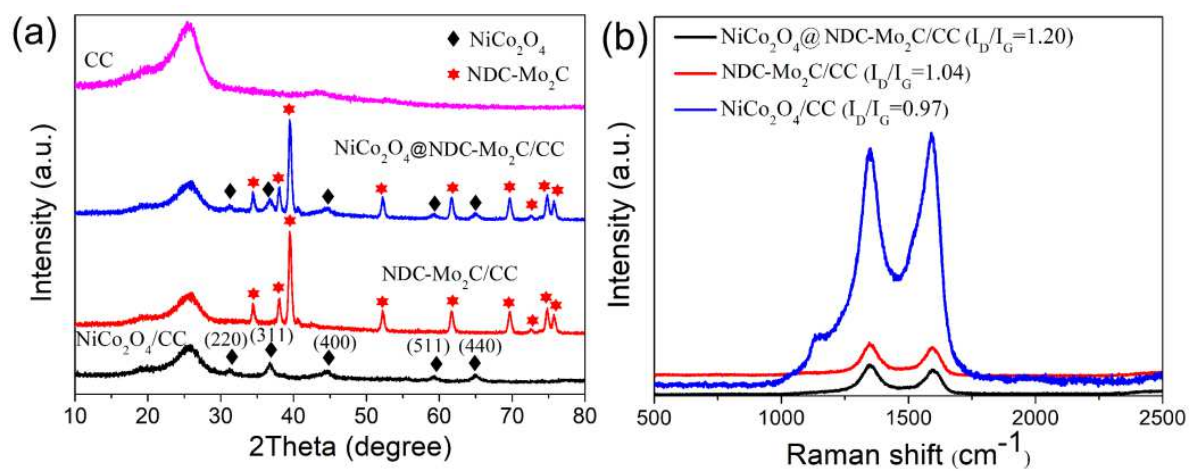

Fig. 1 XRD (a) and Raman patterns (b) of CC, $\mathrm{NiCo}_{2} \mathrm{O}_{4} @ \mathrm{NDC}-\mathrm{Mo}_{2} \mathrm{C} / \mathrm{CC}, \mathrm{NDC}-\mathrm{Mo}_{2} \mathrm{C} / \mathrm{CC}$ and $\mathrm{NiCo}_{2} \mathrm{O}_{4} / \mathrm{CC}$.

Raman spectroscopy was also measured to characterize the prepared catalysts, as exhibited in Fig. 1b. The D and G peaks of composites are found at $1347 \mathrm{~cm}^{-1}$ and $1597 \mathrm{~cm}^{-1}$ respectively. The relative intensity of the D-band to the G-band $\left(\mathrm{I}_{\mathrm{D}} / \mathrm{I}_{\mathrm{G}}\right)$ can be usually employed to reflect the imperfection degree of materials. According to the Raman spectra, the $\mathrm{I}_{\mathrm{D}} / \mathrm{I}_{\mathrm{G}}$ values of $\mathrm{NiCo}_{2} \mathrm{O}_{4} @ \mathrm{NDC}-\mathrm{Mo}_{2} \mathrm{C} / \mathrm{CC}, \mathrm{NDC}-\mathrm{Mo}_{2} \mathrm{C} / \mathrm{CC}$ and $\mathrm{NiCo}_{2} \mathrm{O}_{4} / \mathrm{CC}$ are 1.20, 1.04 and 0.97 respectively, which shows that on the $\mathrm{NiCo}_{2} \mathrm{O}_{4} @ \mathrm{NDC}-\mathrm{Mo}_{2} \mathrm{C} / \mathrm{CC}$ catalysts there have more defects and disordered structures. Therefore, more active sites could be exposed on the surface of 
$\mathrm{NiCo}_{2} \mathrm{O}_{4} @ \mathrm{NDC}-\mathrm{Mo}_{2} \mathrm{C} / \mathrm{CC}$ catalysts, which may effectively promote the catalytic activity.

The chemical composition and electronic feature of the $\mathrm{NiCo}_{2} \mathrm{O}_{4} @ \mathrm{NDC}-\mathrm{Mo}_{2} \mathrm{C} / \mathrm{CC}$ were examined by using the X-ray photoelectron spectroscopy (XPS). The survey scan spectrum in Fig. 2a shows that the surface of $\mathrm{NiCo}_{2} \mathrm{O}_{4} @ \mathrm{NDC}-\mathrm{Mo}_{2} \mathrm{C} / \mathrm{CC}$ is constructed by $\mathrm{Mo}, \mathrm{C}, \mathrm{N}, \mathrm{O}, \mathrm{Ni}$ and Co. From the high-resolution spectrum of Mo 3d (Fig. 2b), the peak located at $231.9 \mathrm{eV}$ is ascribed to the binding energy of $\mathrm{Mo}^{2+}[32,33]$. The $\mathrm{C} 1 \mathrm{~s}$ spectrum is shown in Fig. $3 \mathrm{c}$, and the overlapped peaks can be fitted into three peaks assigned to the $\mathrm{C}-\mathrm{C} / \mathrm{C}=\mathrm{C}(284.5 \mathrm{eV}), \mathrm{C}-\mathrm{N}(285.2 \mathrm{eV})$ and $\mathrm{C}-\mathrm{O}(287.5 \mathrm{eV})$ [34]. The existence of $\mathrm{C}-\mathrm{C} / \mathrm{C}=\mathrm{C}$ proves that the graphitization degree of $\mathrm{NiCo}_{2} \mathrm{O}_{4} @ \mathrm{NDC}-\mathrm{Mo}_{2} \mathrm{C} / \mathrm{CC}$ material is relatively high, which can endow the composite material good conductivity. As for the high-resolution $\mathrm{N}$ 1s XPS spectrum (Fig. 3d), two characteristic peaks at 394.5 and $398.5 \mathrm{eV}$ are assigned to the groups of tertiary amine $(-\mathrm{N}=)$ and secondary ammonium $(-\mathrm{NH}-)$, respectively [35]. This indicates the production of NDC from calcination of PANI. The O 1s peak seen from Fig. 3e can be fitted with two peaks, and the peak at binding energy of $529.7 \mathrm{eV}$ is associated with metal oxygen bond (O1) [36], while the other peak at $531.5 \mathrm{eV}$ is attributed to the chemisorbed oxygen at the oxygen vacancy $(\mathrm{O} 2)$ [37-39]. The peak area ratio of $\mathrm{O} 2$ to $\mathrm{O} 1$ is calculated as $1.9: 1$, indication of large number of oxygen vacancies presented at the $\mathrm{NiCo}_{2} \mathrm{O}_{4}$ crystals. The high resolution XPS spectrum of Ni $2 p$ is shown in Fig. 3f. The peaks located at 855.6 and $873.5 \mathrm{eV}$ and 
two satellite features at 861.7 and $879.8 \mathrm{eV}$ are attributed to $\mathrm{Ni} 2 \mathrm{p}_{3 / 2}$ and $\mathrm{Ni} 2 \mathrm{p}_{1 / 2}$, respectively [40], which indicates the presence of $\mathrm{Ni}^{2+} / \mathrm{Ni}^{3+}$ in the samples. For the high-resolution Co $2 p$ feature (Fig. $3 g$ ), the Co $2 p_{3 / 2}$ and Co $2 p_{1 / 2}$ XPS spectra can be divided into four peaks at binding energies of 780.5, 796.5, 786.9 and $802.8 \mathrm{eV}$ corresponding to $\mathrm{Co}^{2+} / \mathrm{Co}^{3+}$ [41] and their satellites peaks, respectively. All these findings confirm the surface chemistry of $\mathrm{NiCo}_{2} \mathrm{O}_{4} @ \mathrm{NDC}-\mathrm{Mo}_{2} \mathrm{C} / \mathrm{CC}$. As illustrated in Fig. 3h, the conductivity of $\mathrm{Mo}_{2} \mathrm{C} / \mathrm{CC}$ was increased from $14.86 \mathrm{~S} \mathrm{~cm}^{-1}$ to $41.67 \mathrm{~S}$ $\mathrm{cm}^{-1}$ in $\mathrm{NDC}-\mathrm{Mo}_{2} \mathrm{C} / \mathrm{CC}$, because of the presence of NDC. It is further improved to $55.6 \mathrm{~S} \mathrm{~cm}^{-1}$ in the case of $\mathrm{NiCo}_{2} \mathrm{O}_{4} @ \mathrm{NDC}-\mathrm{Mo}_{2} \mathrm{C} / \mathrm{CC}$, due to the $3 \mathrm{D}$ conductive channels formed within the $\mathrm{NiCo}_{2} \mathrm{O}_{4}$. 

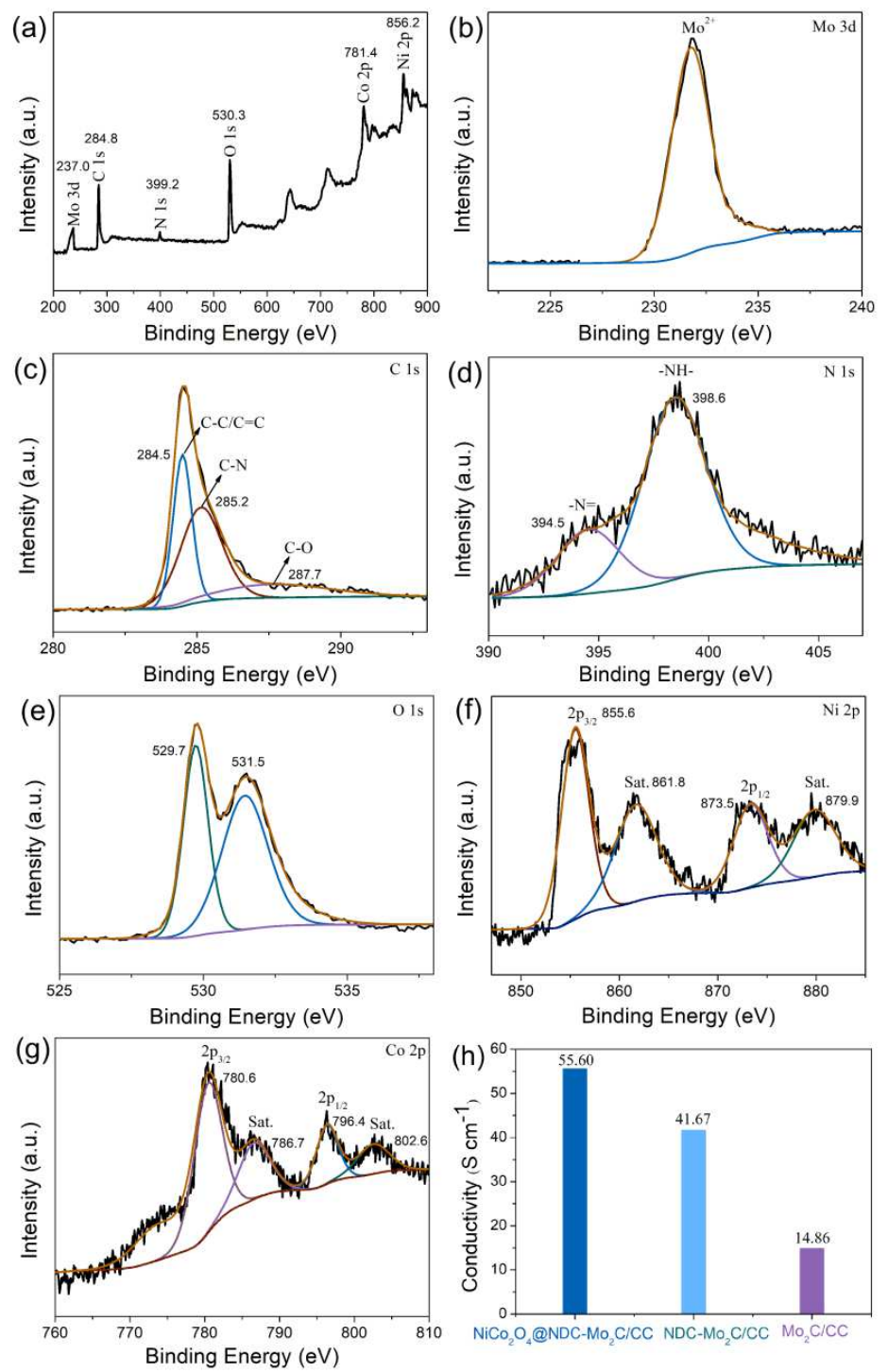

Fig. 2 XPS spectra of $\mathrm{NiCo}_{2} \mathrm{O}_{4} @ \mathrm{NDC}-\mathrm{Mo}_{2} \mathrm{C} / \mathrm{CC}$ : survey scan spectrum (a), Mo 3d spectrum (b), C 1s spectrum (c), N 1s spectrum (d), O 1s spectrum (e), Ni 2p spectrum (f) and Co 2p spectrum (g). the conductivity of catalysts (h).

The micro/nanostructure of the as-prepared catalysts was investigated by using scanning electron microscopy. As shown in Fig. 3, compared with the smooth pure carbon cloth (a), the surface of NDC- $\mathrm{Mo}_{2} \mathrm{C} / \mathrm{CC}$ (b and c) was coarsened due to the coating of a thick densely-stacked layer of $\mathrm{NDC}-\mathrm{Mo}_{2} \mathrm{C}$ on the $\mathrm{CC}$. From Fig. 3c, the NDC- $\mathrm{Mo}_{2} \mathrm{C}$ shows the crooked-layer structure with size of around $580 \mathrm{~nm}$. The EDS spectrum of NDC-Mon $\mathrm{C} / \mathrm{CC}$ (Fig. S1) showed the signals of Mo, C and N 
elements. After further growth of $\mathrm{NiCo}_{2} \mathrm{O}_{4}$ on $\mathrm{NDC}-\mathrm{Mo}_{2} \mathrm{C} / \mathrm{CC}$, luxuriant needle forests are observed on the obtained $\mathrm{NiCo}_{2} \mathrm{O}_{4} @ \mathrm{NDC}-\mathrm{Mo}_{2} \mathrm{C} / \mathrm{CC}$ (Fig. 3d-f). The EDS spectra (Fig. 3h) of $\mathrm{NiCo}_{2} \mathrm{O}_{4} @ \mathrm{NDC}-\mathrm{Mo}_{2} \mathrm{C} / \mathrm{CC}$ suggest that the existence of $\mathrm{Ni}$, Co and $\mathrm{O}$ elements in the samples, which confirms the needle-forests are composed of $\mathrm{NiCo}_{2} \mathrm{O}_{4}$. The diameter of needles on $\mathrm{NiCo}_{2} \mathrm{O}_{4} @ \mathrm{NDC}-\mathrm{Mo}_{2} \mathrm{C} / \mathrm{CC}$ is $\sim 60 \mathrm{~nm}$ (Fig. 3f), which is thinner than that on $\mathrm{NiCo}_{2} \mathrm{O}_{4} / \mathrm{CC}(80 \mathrm{~nm}$, Fig. S2). This is probably because the coating of NDC- $\mathrm{Mo}_{2} \mathrm{C}$ on $\mathrm{CC}$ improves the affinity of $\mathrm{CC}$ towards the aqueous nickel and cobalt ions, repressing the particles aggregation. At the same time, the distribution of needle-forest $\mathrm{NiCo}_{2} \mathrm{O}_{4}$ on $\mathrm{NiCo}_{2} \mathrm{O}_{4} @ \mathrm{NDC}-\mathrm{Mo}_{2} \mathrm{C} / \mathrm{CC}$ is denser than that on $\mathrm{NiCo}_{2} \mathrm{O}_{4} / \mathrm{CC}$. Also, from the SEM images of $\mathrm{NiCo}_{2} \mathrm{O}_{4} @ \mathrm{NDC}-\mathrm{Mo}_{2} \mathrm{C} / \mathrm{CC}$ (Fig. 3d-f), within the $\mathrm{NiCo}_{2} \mathrm{O}_{4}$ forest plenty of micropores are formed, which are interconnected to fabricate 3D roads, beneficial for water adsorption and gas transfer.

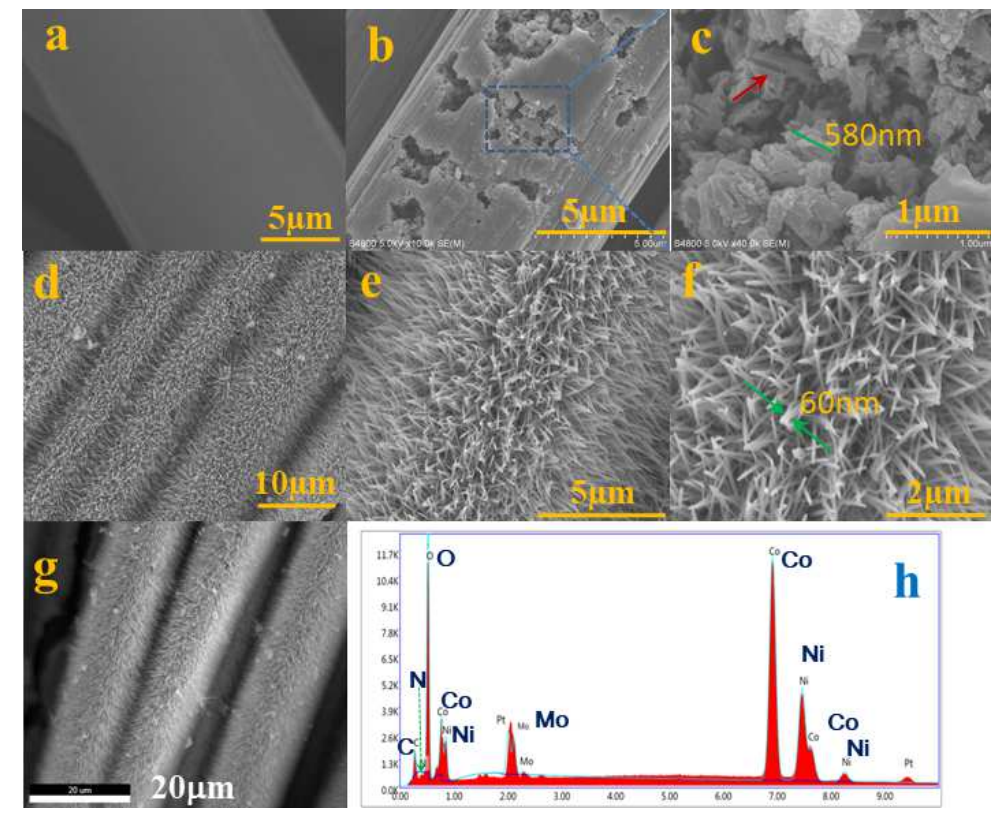

Fig. 3 SEM images of $\mathrm{CC}(\mathrm{a}), \mathrm{NDC}-\mathrm{Mo}_{2} \mathrm{C} / \mathrm{CC}(\mathrm{b}, \mathrm{c}), \mathrm{NiCo}_{2} \mathrm{O}_{4} @ \mathrm{NDC}-\mathrm{Mo}_{2} \mathrm{C} / \mathrm{CC}(\mathrm{d}, \mathrm{e}, \mathrm{f}$ and g). EDS spectrum of $\mathrm{NiCo}_{2} \mathrm{O}_{4} @ \mathrm{NDC}-\mathrm{Mo}_{2} \mathrm{C} / \mathrm{CC}(\mathrm{h})$. 

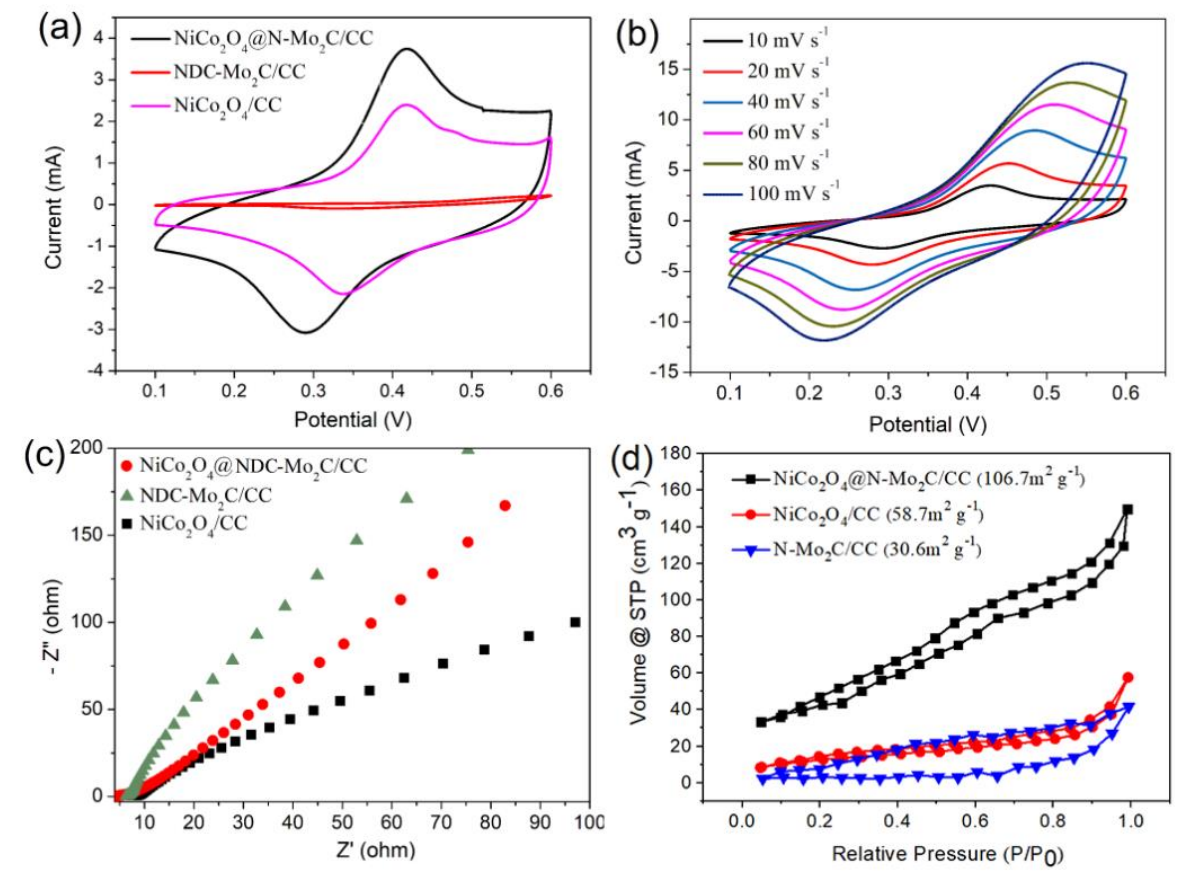

Fig. 4 (a) $\mathrm{CV}$ curves of $\mathrm{NiCo}_{2} \mathrm{O}_{4} @ \mathrm{NDC}-\mathrm{Mo}_{2} \mathrm{C} / \mathrm{CC}$ (b) $\mathrm{CV}$ plots of $\mathrm{NiCo}_{2} \mathrm{O}_{4} @ \mathrm{NDC}-\mathrm{Mo}_{2} \mathrm{C} / \mathrm{CC} \mathrm{NiCo}_{2} \mathrm{O}_{4} @ \mathrm{NDC}-\mathrm{Mo}_{2} \mathrm{C} / \mathrm{CC}$ at different scanning rate. (c) Nyquist plots of the $\mathrm{NiCo}_{2} \mathrm{O}_{4} @ \mathrm{NDC}-\mathrm{Mo}_{2} \mathrm{C} / \mathrm{CC}, \mathrm{NiCo}_{2} \mathrm{O}_{4} / \mathrm{CC}$ and NDC-Mo $2 \mathrm{C} / \mathrm{CC}$. (d) BET nitrogen adsorption and desorption isotherms of the $\mathrm{NiCo}_{2} \mathrm{O}_{4} @ \mathrm{NDC}-\mathrm{Mo}_{2} \mathrm{C} / \mathrm{CC}, \mathrm{NiCo}_{2} \mathrm{O}_{4} / \mathrm{CC}$ and $\mathrm{NDC}-\mathrm{Mo}_{2} \mathrm{C} / \mathrm{CC}$.

The cyclic voltammetric (CV) measurements of $\mathrm{NiCo}_{2} \mathrm{O}_{4} @ \mathrm{NDC}-\mathrm{Mo}_{2} \mathrm{C} / \mathrm{CC}$, $\mathrm{NiCo}_{2} \mathrm{O}_{4} / \mathrm{CC}$ and $\mathrm{NDC}-\mathrm{Mo}_{2} \mathrm{C} / \mathrm{CC}$ were performed on a work station by using three-electrode system at a scanning rate of $10 \mathrm{mV} \mathrm{s}^{-1}$ in $1 \mathrm{M} \mathrm{KOH}$ electrolyte. As shown in Fig. $4 \mathrm{a}$, there were no peaks at $\mathrm{NDC}-\mathrm{Mo}_{2} \mathrm{C} / \mathrm{CC}$ electrode, indicating that no significant electrochemical reactions occur at the $\mathrm{NDC}-\mathrm{Mo}_{2} \mathrm{C} / \mathrm{CC}$. The $\mathrm{NiCo}_{2} \mathrm{O}_{4} / \mathrm{CC}$ has a pair of distinct redox peaks located around $0.41 / 0.34 \mathrm{~V}$ (Fig. 4a), corresponding to the reversible $\mathrm{Co}^{2+} / \mathrm{Co}^{3+}$ and $\mathrm{Ni}^{2+} / \mathrm{Ni}^{3+}$ transitions in alkaline medium [42]. However, for $\mathrm{NiCo}_{2} \mathrm{O}_{4} @ \mathrm{NDC}-\mathrm{Mo}_{2} \mathrm{C} / \mathrm{CC}$ electrode, the integral area of the CV curve is enhanced. This shows that the composite has excellent 
conductivity, which leads to higher peak current of $\mathrm{NiCo}_{2} \mathrm{O}_{4} @ \mathrm{NDC}-\mathrm{Mo}_{2} \mathrm{C} / \mathrm{CC}$ than the other samples. The $\mathrm{CV}$ curves of $\mathrm{NiCo}_{2} \mathrm{O}_{4} @ \mathrm{NDC}-\mathrm{Mo}_{2} \mathrm{C} / \mathrm{CC}$ composite at different scanning speeds in the range $10-100 \mathrm{mV} \mathrm{s}^{-1}$ are illustrated in Fig. 4b. As can be seen from the graphs, the shape of the $\mathrm{CV}$ curves for $\mathrm{NiCo}_{2} \mathrm{O}_{4} @ \mathrm{NDC}-\mathrm{Mo}_{2} \mathrm{C} / \mathrm{CC}$ remains basically unchanged with the increase of the scanning rate, indicating that the composite can be rapidly redox transformed. In addition, with the increase of scanning rate, the oxidation peak and the reduction peak move to the positive and negative directions respectively, and the potential difference between the oxidation peak and the reduction peak improves. This is because with the increment of scanning rate, the resistance of ion diffusion within the material increases too. From the Nyquist plots of the $\mathrm{NiCo}_{2} \mathrm{O}_{4} @ \mathrm{NDC}-\mathrm{Mo}_{2} \mathrm{C} / \mathrm{CC}, \mathrm{NiCo}_{2} \mathrm{O}_{4} / \mathrm{CC}$ and $\mathrm{NDC}-\mathrm{Mo}_{2} \mathrm{C} / \mathrm{CC}$ shown in Fig. 4c, the $\mathrm{NiCo}_{2} \mathrm{O}_{4} @ \mathrm{NDC}-\mathrm{Mo}_{2} \mathrm{C} / \mathrm{CC}$ electrode has lower resistance to the electrolyte diffusion [43], based on the smallest intercept at the $\mathrm{x}$ axis. The results show that $\mathrm{NiCo}_{2} \mathrm{O}_{4} @ \mathrm{NDC}-\mathrm{Mo}_{2} \mathrm{C} / \mathrm{CC}$ has larger active surface area and faster diffusion rate of electrolyte ions. From the Brunauer-Emmett-Teller (BET) curves shown in Fig. 4d, the special surface area of $\mathrm{NiCo}_{2} \mathrm{O}_{4} @ \mathrm{NDC}-\mathrm{Mo}_{2} \mathrm{C} / \mathrm{CC}$ is $106.7 \mathrm{~m}^{2}$ $\mathrm{g}^{-1}$, significantly higher than NDC-Mo $2 \mathrm{C} / \mathrm{CC}\left(30.6 \mathrm{~m}^{2} \mathrm{~g}^{-1}\right)$ and $\mathrm{NiCo}_{2} \mathrm{O}_{4} / \mathrm{CC}\left(58.7 \mathrm{~m}^{2}\right.$ $\mathrm{g}^{-1}$ ). The difference of specific surface area between $\mathrm{NiCo}_{2} \mathrm{O}_{4} @ \mathrm{NDC}-\mathrm{Mo}_{2} \mathrm{C} / \mathrm{CC}$ and $\mathrm{NiCo}_{2} \mathrm{O}_{4} / \mathrm{CC}$ is due to the introduction of NDC- $\mathrm{Mo}_{2} \mathrm{C}$, which enhances the interfacial corporation between $\mathrm{Ni}^{2+}, \mathrm{Co}^{2+}$ and $\mathrm{CC}$, and makes $\mathrm{NiCo}_{2} \mathrm{O}_{4}$ nanoneedles slowly grow to be thinner. The size decrease of $\mathrm{NiCo}_{2} \mathrm{O}_{4}$ increases the specific surface area of the materials. The highest specific surface area of $\mathrm{NiCo}_{2} \mathrm{O}_{4} @ \mathrm{NDC}-\mathrm{Mo}_{2} \mathrm{C} / \mathrm{CC}$ 
supports a largest number of ionic diffusion channels, leading to largest CV integral area, compared with NDC- $\mathrm{Mo}_{2} \mathrm{C} / \mathrm{CC}$ and $\mathrm{NiCo}_{2} \mathrm{O}_{4} / \mathrm{CC}$.

Table 1 Comparison of HER and OER performances between the $\mathrm{NiCo}_{2} \mathrm{O}_{4} @ \mathrm{NDC}-\mathrm{Mo}_{2} \mathrm{C} / \mathrm{CC}$ and the reported $\mathrm{Mo}_{2} \mathrm{C}$ or $\mathrm{NiCo}_{2} \mathrm{O}_{4}$ based materials.

\begin{tabular}{|c|c|c|c|}
\hline Materials & Over-potential (mV) & Current $\left(\mathrm{mA} \mathrm{cm}^{-2}\right)$ & Reference \\
\hline $\mathrm{Mo} / \mathrm{Mo}_{2} \mathrm{C} / \mathrm{N}-\mathrm{CFS}$ & 162 (HER) & 10 & {$[44]$} \\
\hline Graphene/ $\mathrm{Mo}_{2} \mathrm{C}$ & 270 (HER) & 10 & {$[45]$} \\
\hline $\mathrm{Mo}_{2} \mathrm{C} @ \mathrm{C}$ & 140 (HER) & 10 & {$[46]$} \\
\hline 2D Mo $2 \mathrm{C}-\mathrm{C}$ & 110 (HER) & 10 & {$[47]$} \\
\hline $\mathrm{N}, \mathrm{P}$-doped $\mathrm{Mo}_{2} \mathrm{C}$ & 121 (HER) & 10 & [48] \\
\hline $\mathrm{NiCo}_{2} \mathrm{O}_{4} @ \mathrm{NDC}-\mathrm{Mo}_{2} \mathrm{C} / \mathrm{CC}$ & 120 (HER) & 10 & This Work \\
\hline $\mathrm{NiO}_{\mathrm{x}} / \mathrm{NiCo}_{2} \mathrm{O}_{4} / \mathrm{Co}_{3} \mathrm{O}_{4}$ & 315 (OER) & 10 & [49] \\
\hline $\mathrm{NiCo}_{2} \mathrm{O}_{4}$ Naonosheets & 290 (OER) & 10 & {$[50]$} \\
\hline $\mathrm{NiO} / \mathrm{NiCo}_{2} \mathrm{O}_{4}$ & 264 (OER) & 10 & {$[51]$} \\
\hline $\mathrm{CoFe}-\mathrm{LDH} / \mathrm{NCO} / \mathrm{NF}$ & 273 (OER) & 20 & {$[52]$} \\
\hline $\mathrm{MnO}_{2} / \mathrm{NiCo}_{2} \mathrm{O}_{4} / \mathrm{NF}$ & 340 (OER) & 10 & {$[53]$} \\
\hline $\mathrm{NiCo}_{2} \mathrm{O}_{4}-\mathrm{G}-\mathrm{NCD}$ & 308 (OER) & 10 & {$[54]$} \\
\hline Rosettes-like $\mathrm{NiCo}_{2} \mathrm{O}_{4}$ & 155 (OER) & 10 & {$[55]$} \\
\hline $\mathrm{NiCo}_{2} \mathrm{O}_{4} @ \mathrm{NDC}-\mathrm{Mo}_{2} \mathrm{C} / \mathrm{CC}$ & 220 (OER) & 10 & This Work \\
\hline
\end{tabular}

To evaluate the electrocatalytic HER performance, a three-electrode cell composed of the as-prepared $\mathrm{NiCo}_{2} \mathrm{O}_{4} @ \mathrm{NDC}-\mathrm{Mo}_{2} \mathrm{C} / \mathrm{CC}$ (working electrode), carbon rod (counter electrode) and $\mathrm{Hg} / \mathrm{HgO}$ (reference electrode) was tested in $1 \mathrm{M}$ 
$\mathrm{KOH}$ at $10 \mathrm{mV} \mathrm{s}^{-1}$ from $0 \mathrm{~V}$ to $-1.4 \mathrm{~V}$. The $\mathrm{NiCo}_{2} \mathrm{O}_{4} / \mathrm{CC}, \mathrm{NDC}-\mathrm{Mo}_{2} \mathrm{C} / \mathrm{CC}$ and commercial Pt/C electrodes were also characterized for comparison. In Fig. 5a, it can be observed that $\mathrm{NiCo}_{2} \mathrm{O}_{4} @ \mathrm{NDC}-\mathrm{Mo}_{2} \mathrm{C} / \mathrm{CC}$ is highly electrocatalytic active, which displays better HER property than the other samples. At the current density of $10 \mathrm{~mA}$ $\mathrm{cm}^{-2}$, the overpotential corresponding to $\mathrm{NiCo}_{2} \mathrm{O}_{4} @ \mathrm{NDC}-\mathrm{Mo}_{2} \mathrm{C} / \mathrm{CC}, \mathrm{NiCo}_{2} \mathrm{O}_{4} / \mathrm{CC}$, $\mathrm{NDC}-\mathrm{Mo}_{2} \mathrm{C} / \mathrm{CC}$ and commercial $\mathrm{Pt} / \mathrm{C}$ are $-120 \mathrm{mV},-432 \mathrm{mV},-546 \mathrm{mV}$ and $-15 \mathrm{mV}$, respectively. At the same current density, the overpotential of $\mathrm{NiCo}_{2} \mathrm{O}_{4} @ \mathrm{NDC}-\mathrm{Mo}_{2} \mathrm{C} / \mathrm{CC}$ is smaller and closer to that of commercial Pt/C. It indicates that the incorporation of $\mathrm{NiCo}_{2} \mathrm{O}_{4}$ on $\mathrm{NDC}-\mathrm{Mo}_{2} \mathrm{C} / \mathrm{CC}$ can largely enhance the HER activity. This is because a large number of oxygen vacancy sites presented at the $\mathrm{NiCo}_{2} \mathrm{O}_{4}$ crystals accommodate the water adsorption and splitting. In addition, the NDC composited with $\mathrm{Mo}_{2} \mathrm{C}$ improves the conductivity, which facilitates the electron transfer and desorption of hydrogen. It is noted that the overpotential for $\mathrm{NiCo}_{2} \mathrm{O}_{4} @ \mathrm{NDC}-\mathrm{Mo}_{2} \mathrm{C} / \mathrm{CC}$ is even lower than the reported $\mathrm{Mo} / \mathrm{Mo}_{2} \mathrm{C} / \mathrm{N}-\mathrm{CFS}$ [44], graphene/ $\mathrm{Mo}_{2} \mathrm{C}$ [45] and $\mathrm{Mo}_{2} \mathrm{C} @ \mathrm{C}$ [46], and near to that of 2D $\mathrm{Mo}_{2} \mathrm{C}-\mathrm{C}$ [47] and $\mathrm{N}, \mathrm{P}$-doped $\mathrm{Mo}_{2} \mathrm{C}$ [48], as summarized in Table 1.

In addition, the Tafel slope is another essential parameter reflecting the performance of hydrogen evolution, which shows the hindrance of the electrode reaction. The HER kinetics of the catalysts were investigated by analyzing Tafel plots (Fig. 5b), which reveal that the Tafel slope of the $\mathrm{NiCo}_{2} \mathrm{O}_{4} / \mathrm{CC}$ and $\mathrm{NDC}-\mathrm{Mo}_{2} \mathrm{C} / \mathrm{CC}$ were 117 and $357 \mathrm{mV} \operatorname{dec}^{-1}$, respectively. In comparison, the

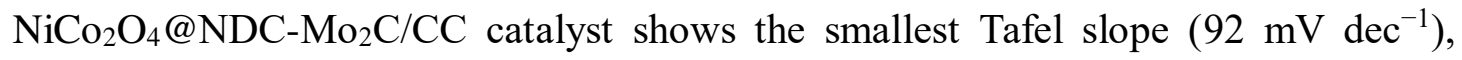


which indicates that it has the closest hydrogen evolution efficiency to $\mathrm{Pt} / \mathrm{C}(80 \mathrm{mV}$ $\left.\operatorname{dec}^{-1}\right)$. To estimate the potential application, the HER stability of $\mathrm{NiCo}_{2} \mathrm{O}_{4} @ \mathrm{NDC}-\mathrm{Mo}_{2} \mathrm{C} / \mathrm{CC}$ was then assessed by long-duration chronoamperometry (Fig. 5c) and the LSV curves before and after the cycled test (Fig. 5d). Not only the i-t curve of the $\mathrm{NiCo}_{2} \mathrm{O}_{4} @ \mathrm{NDC}-\mathrm{Mo}_{2} \mathrm{C} / \mathrm{CC}$ catalyst at -1.3 , -1.4 and $-1.5 \mathrm{~V}$ exhibits a negligible current decay (Fig. 5c), but also its polarization curve remains almost unchanged before and after i-t test (Fig. 5d). The durability results indicate clearly that $\mathrm{NiCo}_{2} \mathrm{O}_{4} @ \mathrm{NDC}-\mathrm{Mo}_{2} \mathrm{C} / \mathrm{CC}$ catalysts exhibit a superior long-term stability owing to the enhanced conductivity from NDC and the strong mechanical support from CC.
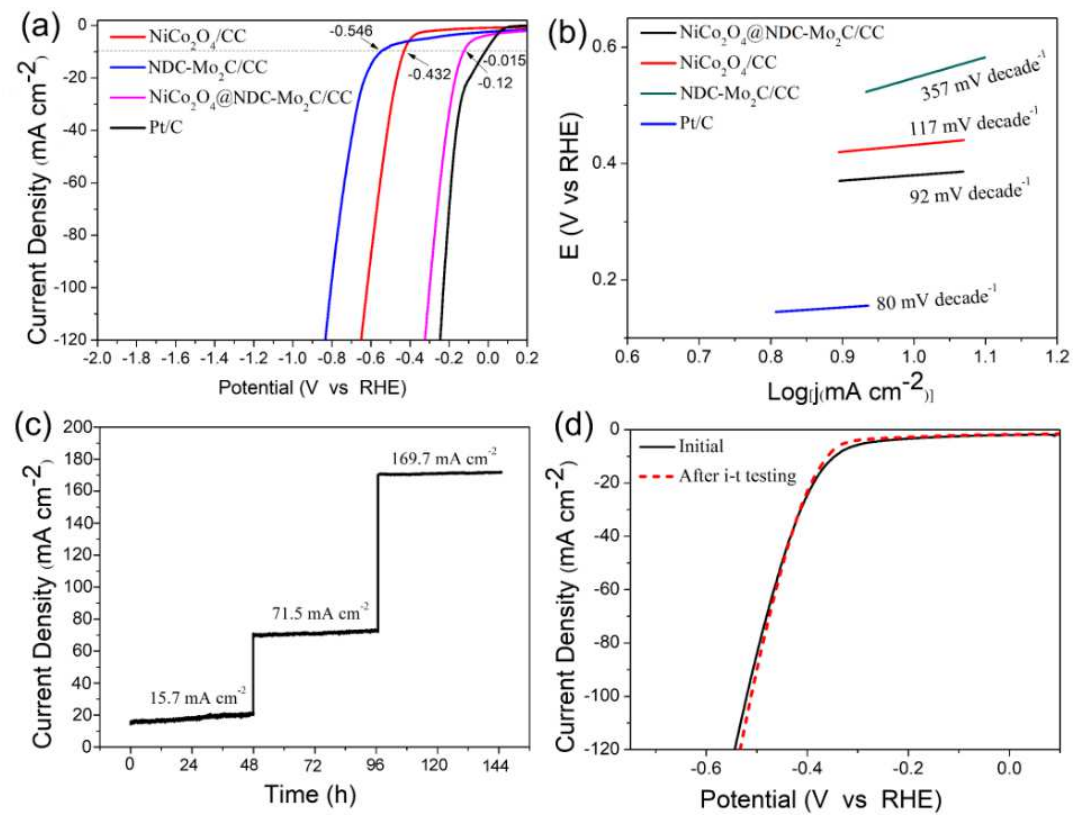

Fig. 5 (a) HER polarization curves of $\mathrm{NiCo}_{2} \mathrm{O}_{4} @ \mathrm{NDC}-\mathrm{Mo}_{2} \mathrm{C} / \mathrm{CC}$ in $1 \mathrm{M} \mathrm{KOH}$ electrolytes at $1 \mathrm{mV} \mathrm{s}^{-1}$, along with plots of $\mathrm{NiCo}_{2} \mathrm{O}_{4} / \mathrm{CC}, \mathrm{NDC}-\mathrm{Mo}_{2} \mathrm{C} / \mathrm{CC}$ and $\mathrm{Pt} / \mathrm{C}$ for comparison. (b) Corresponding Tafel plots. (c) The i-t curve of $\mathrm{NiCo}_{2} \mathrm{O}_{4} @ \mathrm{NDC}-\mathrm{Mo}_{2} \mathrm{C} / \mathrm{CC}$ at $-1.3,-1.4$ and $-1.5 \mathrm{~V}$. (d) LSV curves of $\mathrm{NiCo}_{2} \mathrm{O}_{4} @ \mathrm{NDC}-\mathrm{Mo}_{2} \mathrm{C} / \mathrm{CC}$ before and after i-t test.

As a bifunctional electrocatalyst, it must have excellent HER and OER catalytic 
activity in the same electrolyte. Thus, the OER performance of the prepared electrocatalysts has been studied in the potential range of 1.0 1.8 V (RHE) by means similar to HER, and compared with iridium oxide $\left(\mathrm{IrO}_{2}\right)$. From Fig. 6a, it can be found that the overpotentials corresponding to $\mathrm{NiCo}_{2} \mathrm{O}_{4} @ \mathrm{NDC}-\mathrm{Mo}_{2} \mathrm{C} / \mathrm{CC}$, $\mathrm{NiCo}_{2} \mathrm{O}_{4} / \mathrm{CC}, \mathrm{NDC}-\mathrm{Mo}_{2} \mathrm{C} / \mathrm{CC}$ and commercial $\mathrm{IrO}_{2}$ are $220 \mathrm{mV}, 290 \mathrm{mV}, 370 \mathrm{mV}$ and $190 \mathrm{mV}$, respectively. Thus, the overpotential of $\mathrm{NiCo}_{2} \mathrm{O}_{4} @ \mathrm{NDC}-\mathrm{Mo}_{2} \mathrm{C} / \mathrm{CC}$ catalysts is the closest to that of $\mathrm{IrO}_{2} @ 10 \mathrm{mV} \mathrm{cm}^{-2}$ compared with other catalysts. Also, the overpotential of $\mathrm{NiCo}_{2} \mathrm{O}_{4} @ \mathrm{NDC}-\mathrm{Mo}_{2} \mathrm{C} / \mathrm{CC}$ shows lower value than the reported similar $\mathrm{NiCo}_{2} \mathrm{O}_{4}$-based materials, such as $\mathrm{NiO}_{x} / \mathrm{NiCo}_{2} \mathrm{O}_{4} / \mathrm{Co}_{3} \mathrm{O}_{4}$ [49], $\mathrm{NiCo}_{2} \mathrm{O}_{4}$ naonosheets [50], $\mathrm{NiO} / \mathrm{NiCo}_{2} \mathrm{O}_{4} \quad[51], \quad \mathrm{CoFe}-\mathrm{LDH} / \mathrm{NCO} / \mathrm{NF} \quad$ [52], $\mathrm{MnO}_{2} / \mathrm{NiCo}_{2} \mathrm{O}_{4} / \mathrm{NF}$ [53] and $\mathrm{NiCo}_{2} \mathrm{O}_{4}-\mathrm{G}-\mathrm{NCD}$ [54]. It is just relatively higher than that of $\mathrm{NiCo}_{2} \mathrm{O}_{4}$ rosettes-like hierarchical spinel (155 mV) [55], as shown in Table 1. In Fig. 6b, the result of Tafel slope also corresponds to the above conclusion. Compared with $\mathrm{NiCo}_{2} \mathrm{O}_{4} / \mathrm{CC}$ and $\mathrm{NDC}-\mathrm{Mo}_{2} \mathrm{C} / \mathrm{CC}$, only the Tafel slope of $\mathrm{NiCo}_{2} \mathrm{O}_{4} @ \mathrm{NDC}-\mathrm{Mo}_{2} \mathrm{C} / \mathrm{CC}$ material is closest to $\mathrm{IrO}_{2}$. The reason is that the NDC-Mo $\mathrm{M}_{2} \mathrm{C}$ layer between $\mathrm{NiCo}_{2} \mathrm{O}_{4}$ and $\mathrm{CC}$ adjusted the electron transfer by interface engineering, and the plenty of oxygen vacancies on the $\mathrm{NiCo}_{2} \mathrm{O}_{4}$ needles accommodated the water adsorption and splitting. These results are all favorable to its outstanding OER performance. From Table $\mathrm{S} 1, \mathrm{O}_{2}$ turn over frequencies (TOFs) prove the high electrocatalytic activity of $\mathrm{NiCo}_{2} \mathrm{O}_{4} @ \mathrm{NDC}-\mathrm{Mo}_{2} \mathrm{C} / \mathrm{CC}$ electrode, which are obviously larger than that of $\mathrm{NiCo}_{2} \mathrm{O}_{4} / \mathrm{CC}$ and $\mathrm{NDC}-\mathrm{Mo}_{2} \mathrm{C} / \mathrm{CC}$ at the same overpotential. Moreover, the TOF value is increased with the increase of overpotential. 
This indicates that the quantity of $\mathrm{O}_{2}$ induced by the current flow was proportional to the amount of electricity passed through the samples.
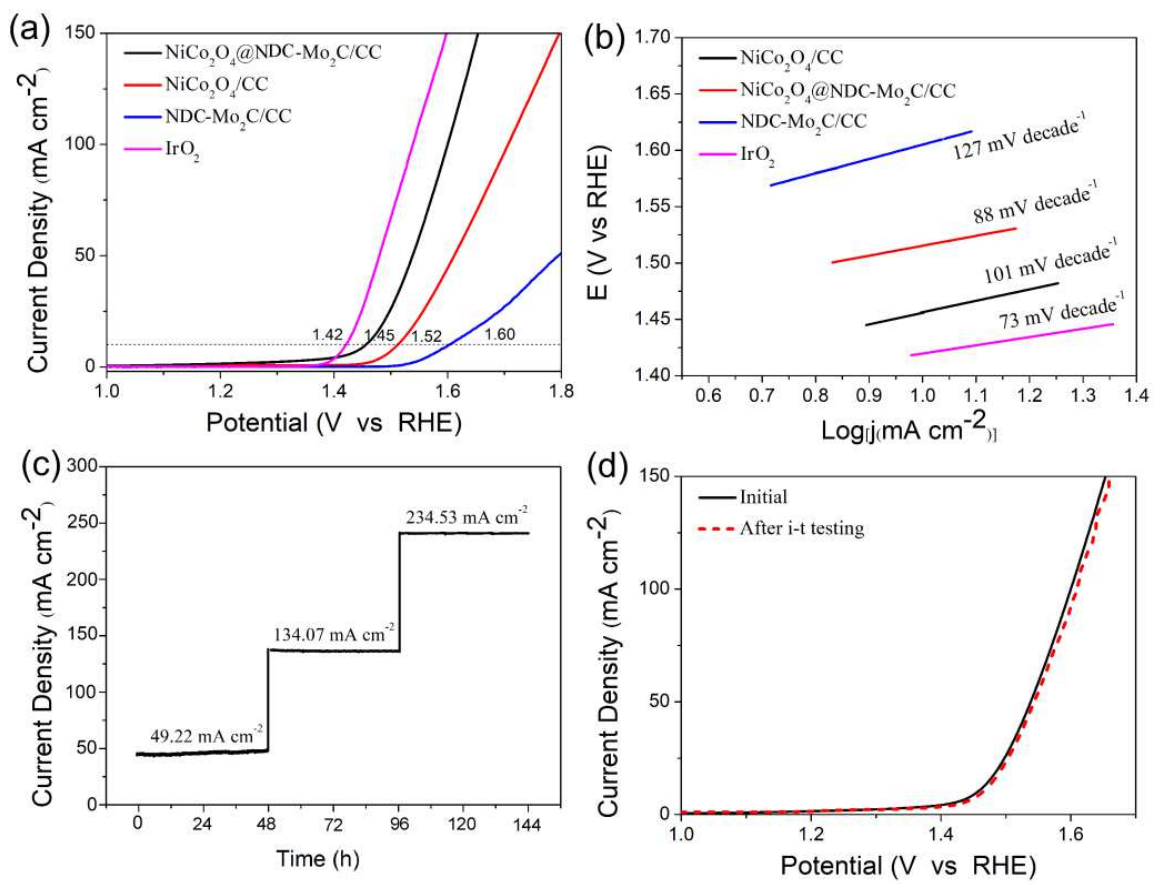

Fig. 6 (a) OER polarization curves of $\mathrm{NiCo}_{2} \mathrm{O}_{4} @ \mathrm{NDC}-\mathrm{Mo}_{2} \mathrm{C} / \mathrm{CC}$ in $1 \mathrm{M} \mathrm{KOH}$ electrolytes at $1 \mathrm{mV} \mathrm{s}^{-1}$, along with plots of $\mathrm{NiCo}_{2} \mathrm{O}_{4} / \mathrm{CC}, \mathrm{NDC}-\mathrm{Mo}_{2} \mathrm{C} / \mathrm{CC}$ and $\mathrm{Pt} / \mathrm{C}$ for comparison. (b) Corresponding Tafel plots. (c) The i-t curve of $\mathrm{NiCo}_{2} \mathrm{O}_{4} @ \mathrm{NDC}-\mathrm{Mo}_{2} \mathrm{C} / \mathrm{CC}$ at $0.7,0.8$ and 0.9 V. (d) LSV curves of $\mathrm{NiCo}_{2} \mathrm{O}_{4} @ \mathrm{NDC}-\mathrm{Mo}_{2} \mathrm{C} / \mathrm{CC}$ before and after i-t test.

Fig. $6 \mathrm{c}$ and d show the chronoamperometry curves of $\mathrm{NiCo}_{2} \mathrm{O}_{4} @ \mathrm{NDC}-\mathrm{Mo}_{2} \mathrm{C} / \mathrm{CC}$ composites which were measured at static voltages of $0.7 \mathrm{~V}, 0.8 \mathrm{~V}$ and $0.9 \mathrm{~V}$, and its LSV curves before and after i-t test show that $\mathrm{NiCo}_{2} \mathrm{O}_{4} @ \mathrm{NDC}-\mathrm{Mo}_{2} \mathrm{C} / \mathrm{CC}$ composites also have sterling stability for OER.

As an important parameter to compare the active surface area of different catalysts, electrochemical double layer capacitance (EDLC) of the as-prepared catalysts is measured. By means of the $\mathrm{CV}$ detected at different scan rates (Fig. $\mathrm{S} 3 \mathrm{a}-\mathrm{c})$, a linear relationship between the current density and scan rate is given in 
Fig. S3d. The linear slope can reflect the EDLC, which directly correlates with the catalytic behavior. The EDLC of $\mathrm{NiCo}_{2} \mathrm{O}_{4} @ \mathrm{NDC}-\mathrm{Mo}_{2} \mathrm{C} / \mathrm{CC}, \mathrm{NiCo}_{2} \mathrm{O}_{4} / \mathrm{CC}$ and $\mathrm{NDC}-\mathrm{Mo}_{2} \mathrm{C} / \mathrm{CC}$ are $0.033,0.028$ and $0.0009 \mathrm{mF} \mathrm{cm}^{-2}$, which corresponds to the electrochemical active surface area (ECSA) of $0.83,0.7$ and $0.02 \mathrm{~cm}^{2}$ (Fig. S3e), respectively. Therefore, the $\mathrm{NiCo}_{2} \mathrm{O}_{4} @ \mathrm{NDC}-\mathrm{Mo}_{2} \mathrm{C} / \mathrm{CC}$ presents a largest ECSA value. These results support the $\mathrm{NiCo}_{2} \mathrm{O}_{4} @ \mathrm{NDC}-\mathrm{Mo}_{2} \mathrm{C} / \mathrm{CC}$ has the best electrocatalytic activity among the as-derived catalysts.
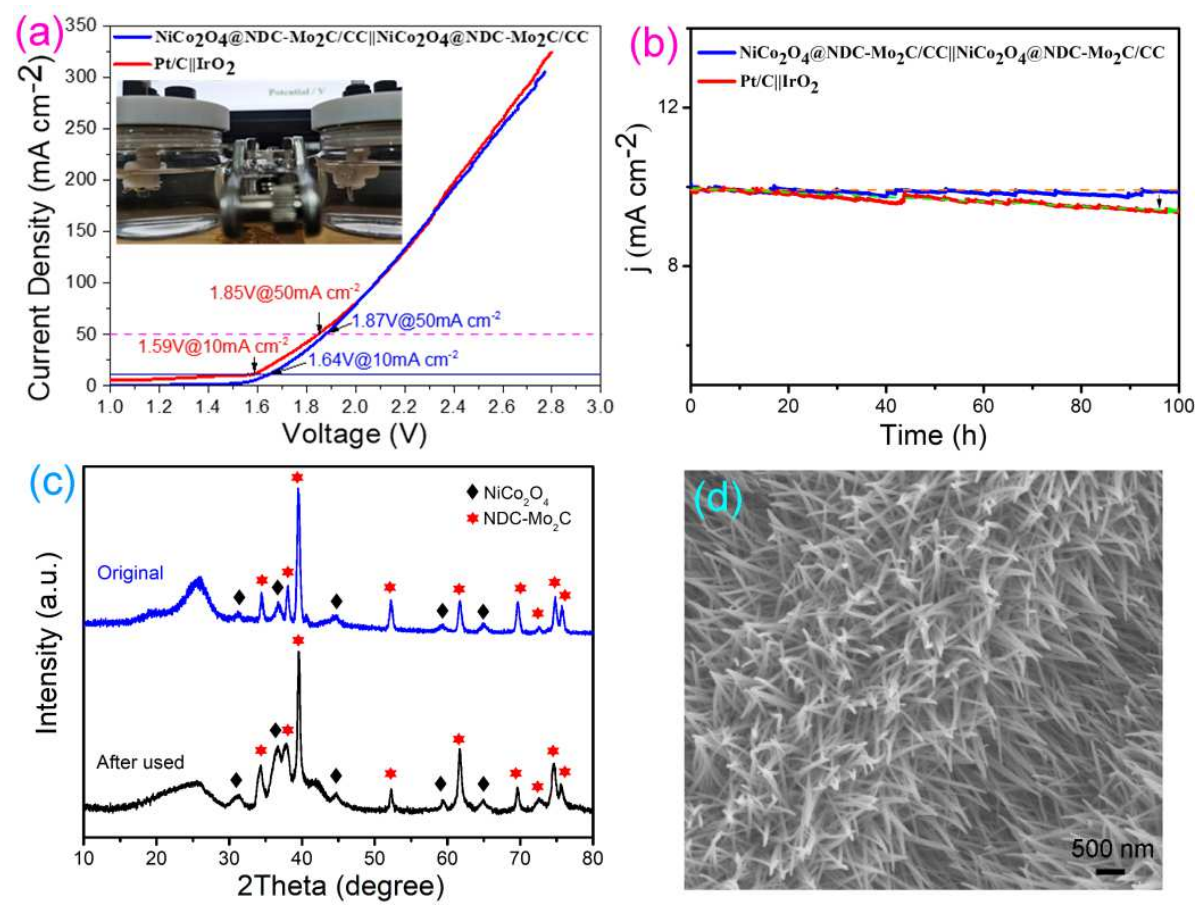

Fig. 7 (a) LSV plot of $\mathrm{NiCo}_{2} \mathrm{O}_{4} @ \mathrm{NCD}-\mathrm{Mo}_{2} \mathrm{C} / \mathrm{CC}$ and $\mathrm{Pt} / \mathrm{C} \| \mathrm{IrO}_{2}$ for overall water splitting in 1.0 $\mathrm{M} \mathrm{KOH}$ electrolytes. Inset shows the hydrogen and oxygen gas bubbles released from the splitter cell. (b) Long-term stability of $\mathrm{NiCo}_{2} \mathrm{O}_{4} @ \mathrm{NCD}-\mathrm{Mo}_{2} \mathrm{C} / \mathrm{CC}$ and $\mathrm{Pt} / \mathrm{C}+\mathrm{IrO}_{2}$ at $10 \mathrm{~mA}$ $\mathrm{cm}^{-2}$. (c) XRD patterns of $\mathrm{NiCo}_{2} \mathrm{O}_{4} @ \mathrm{NCD}-\mathrm{Mo}_{2} \mathrm{C} / \mathrm{CC}$ before and after overall water splitting. (d) SEM image of $\mathrm{NiCo}_{2} \mathrm{O}_{4} @ \mathrm{NCD}-\mathrm{Mo}_{2} \mathrm{C} / \mathrm{CC}$ after overall water splitting.

Because $\mathrm{NiCo}_{2} \mathrm{O}_{4} @ \mathrm{NCD}-\mathrm{Mo}_{2} \mathrm{C} / \mathrm{CC}$ electrodes have demonstrated excellent electrocatalytic activity towards both OER and HER, therefore, the overall water 
splitting was investigated by using $\mathrm{NiCo}_{2} \mathrm{O}_{4} @ \mathrm{NCD}-\mathrm{Mo}_{2} \mathrm{C} / \mathrm{CC}$ as both the anode and cathode in $1 \mathrm{M} \mathrm{KOH}$ in a two-electron configuration (inset in Fig. 7a). From the polarization curve in Fig. 7a, a low external bias of $1.64 \mathrm{~V} @ 10 \mathrm{~mA} \mathrm{~cm}{ }^{-2}$ and $1.87 \mathrm{~V} @ 50 \mathrm{~mA} \mathrm{~cm}{ }^{-2}$ was observed, with hydrogen and oxygen gas bubbles continuously released (inset of Fig. 7a). Furthermore, $\mathrm{NiCo}_{2} \mathrm{O}_{4} @ \mathrm{NCD}-\mathrm{Mo}_{2} \mathrm{C} / \mathrm{CC}$ electrodes in this work show an external bias voltage close to the commercial $\mathrm{Pt} / \mathrm{C} \| \mathrm{IrO}_{2}$ pair (Fig. 8a), and also lower than the reported $\mathrm{NiFe}-\mathrm{NiCoO}_{2}$ [56], $\mathrm{NFP} @ \mathrm{NG}$ [57], $\mathrm{Ni}(\mathrm{OH})_{2} / \mathrm{NiCo}_{2} \mathrm{O}_{4}$ [58] and $\mathrm{Co}_{5} \mathrm{Mo}_{1.0} \mathrm{O} \mathrm{NSs} @ \mathrm{NF}$ [59] @10 mA $\mathrm{cm}^{-2}$ shown in Table S2. This is attributed to that the massive oxygen vacancy sites in the nanoneedle arrays of $\mathrm{NiCo}_{2} \mathrm{O}_{4}$ not only allow easy adsorption of water into the electrode but also facilitate the water splitting to quickly generate gas bubbles. In addition, the regulated electron transport of $\mathrm{Mo}_{2} \mathrm{C}$ by nitrogen doping carbon also leads to lowered overvoltage. These results highlight the importance of the chemical or structure regulation in design of low-cost and high-performance electrocatalysts. Moreover, compared with $\mathrm{Pt} / \mathrm{C} \| \mathrm{IrO}_{2}$ pair electrode, $\mathrm{NiCo}_{2} \mathrm{O}_{4} @ \mathrm{NCD}-\mathrm{Mo}_{2} \mathrm{C} / \mathrm{CC} \| \mathrm{NiCo}_{2} \mathrm{O}_{4} @ \mathrm{NCD}-\mathrm{Mo}_{2} \mathrm{C} / \mathrm{CC}$ electrodes demonstrate the constant current density @10 mA cm ${ }^{-2}$ during the 100-h cycling (Fig. 7b). Additionally, the XRD features of $\mathrm{NiCo}_{2} \mathrm{O}_{4} @ \mathrm{NCD}-\mathrm{Mo}_{2} \mathrm{C} / \mathrm{CC}$ show the unchanged shape after cycled (Fig. 7c), with the original needle-forest morphology maintained (Fig. 7d), which indicates high stability in the potential applications. 

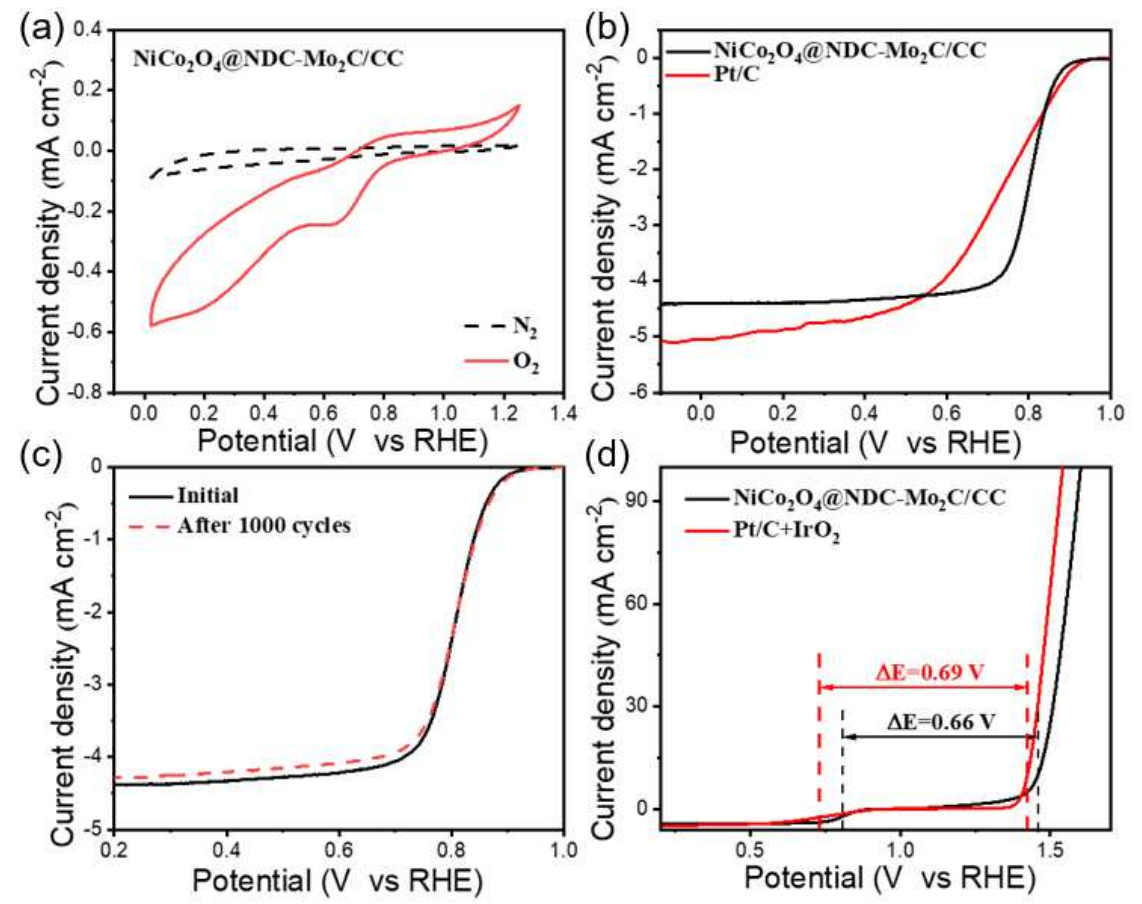

Fig. 8 (a) $\mathrm{CVs}$ of $\mathrm{NiCo}_{2} \mathrm{O}_{4} @ \mathrm{NCD}-\mathrm{Mo}_{2} \mathrm{C} / \mathrm{CC}$ in $\mathrm{N}_{2} / \mathrm{O}_{2}$-saturated $0.1 \mathrm{M} \mathrm{KOH}$ solution. (b)

LSV curves of $\mathrm{NiCo}_{2} \mathrm{O}_{4} @ \mathrm{NCD}-\mathrm{Mo}_{2} \mathrm{C} / \mathrm{CC}$ and $\mathrm{Pt} / \mathrm{C}$. (c) LSV curves of $\mathrm{NiCo}_{2} \mathrm{O}_{4} @ \mathrm{NCD}-\mathrm{Mo}_{2} \mathrm{C} / \mathrm{CC}$ collected before and after $1000 \mathrm{CV}$ cycles. (d) Combined ORR/OER LSV profiles of $\mathrm{NiCo}_{2} \mathrm{O}_{4} @ \mathrm{NCD}-\mathrm{Mo}_{2} \mathrm{C} / \mathrm{CC}$ and $\mathrm{Pt} / \mathrm{C}+\mathrm{IrO}_{2}$.

Interestingly, except the efficient overall water splitting performance demonstrated above, the $\mathrm{NiCo}_{2} \mathrm{O}_{4} @ \mathrm{NCD}-\mathrm{Mo}_{2} \mathrm{C} / \mathrm{CC}$ also exhibits good ORR performance. The cyclic voltammetry curve of $\mathrm{NiCo}_{2} \mathrm{O}_{4} @ \mathrm{NCD}-\mathrm{Mo}_{2} \mathrm{C} / \mathrm{CC}$ in $\mathrm{O}_{2}$-saturated solution illustrates a pronounced cathodic peak, while no peaks could be found in $\mathrm{N}_{2}$-saturated solution (Fig. 8a). As shown in Fig. 8b, the onset potential of $\mathrm{NiCo}_{2} \mathrm{O}_{4} @ \mathrm{NCD}-\mathrm{Mo}_{2} \mathrm{C} / \mathrm{CC}$ is nearly the same as $\mathrm{Pt} / \mathrm{C}$ but showing a far more positive half-wave potential (0.79 V). Moreover, for $\mathrm{NiCo}_{2} \mathrm{O}_{4} @ \mathrm{NCD}-\mathrm{Mo}_{2} \mathrm{C} / \mathrm{CC}$, no obvious decline was found before and after $1000 \mathrm{CV}$ cycles (Fig. 8c), which indicated the excellent electrocatalytic durability of the sample. In the whole region of OER and 
ORR (Fig. 8d), the $\mathrm{NiCo}_{2} \mathrm{O}_{4} @ \mathrm{NCD}-\mathrm{Mo}_{2} \mathrm{C} / \mathrm{CC}$ exhibits a $\Delta \mathrm{E}$ value of $0.66 \mathrm{~V}$, which is smaller than that of the precious $\mathrm{Pt} / \mathrm{C}+\mathrm{IrO}_{2}(0.69 \mathrm{~V})$. Compared by the difference between OER and $\operatorname{ORR}\left(\Delta \mathrm{E}=E_{\mathrm{j}=10}-E_{1 / 2}\right)$, the small difference value $(0.03 \mathrm{~V})$ between $\mathrm{NiCo}_{2} \mathrm{O}_{4} @ \mathrm{NCD}-\mathrm{Mo}_{2} \mathrm{C} / \mathrm{CC}$ and $\mathrm{Pt} / \mathrm{C}+\mathrm{IrO}_{2}$ indicates the ideal reversible property of the as-prepared bifunctional electrode. These results indicate that the $\mathrm{NiCo}_{2} \mathrm{O}_{4} @ \mathrm{NCD}-\mathrm{Mo}_{2} \mathrm{C} / \mathrm{CC}$ has high ORR activity potential as ideal electrocatalysts for Zn-air batteries. 

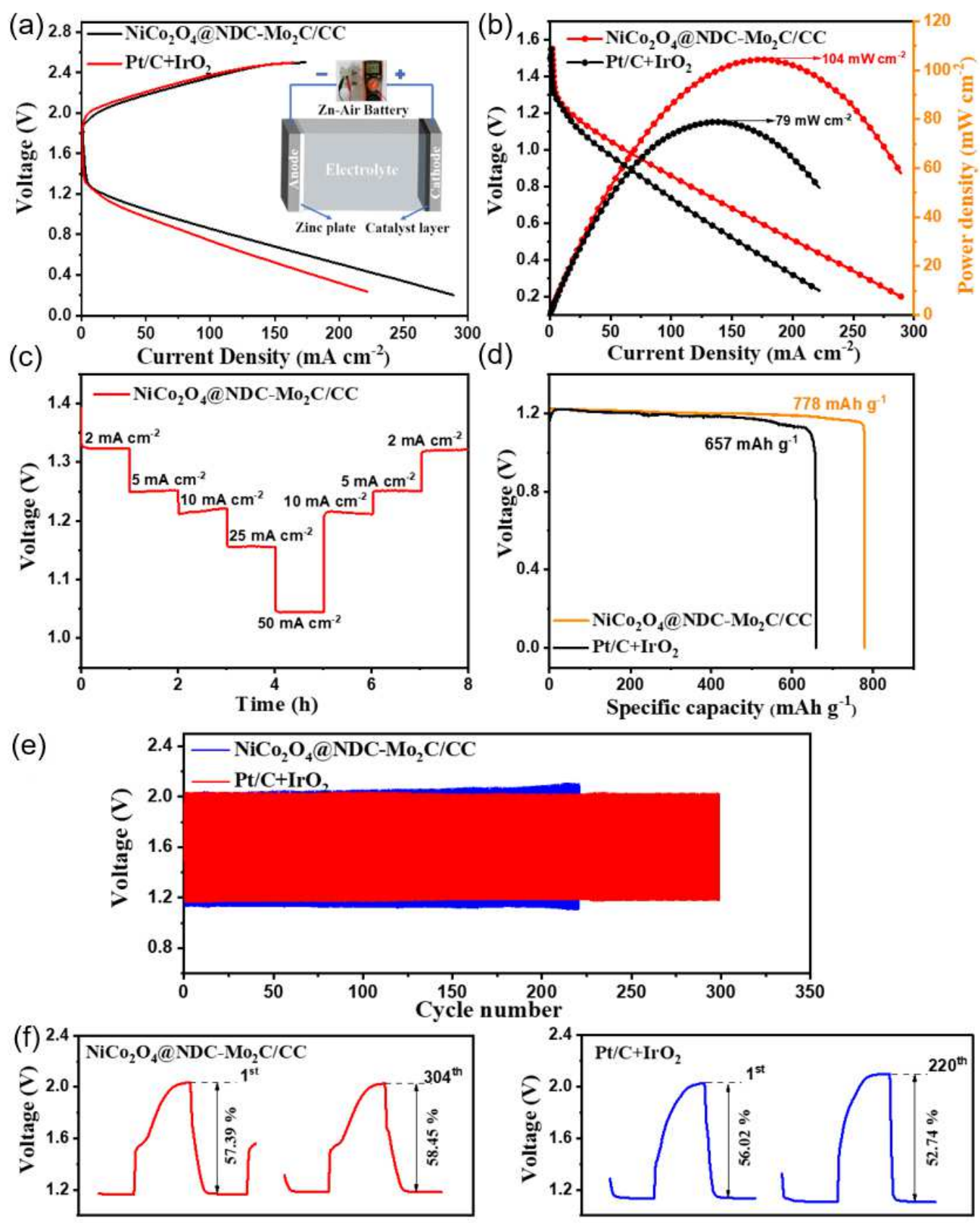

Fig. 9 (a) Charging/discharging polarization curves. Inset in (a) shows the structure of the assembled Zn-air battery. (b) Polarization and corresponding power density profiles. (c) Discharge polarization plots at different current densities. (d) Discharge polarization curves of $\mathrm{NiCo}_{2} \mathrm{O}_{4} @ \mathrm{NCD}-\mathrm{Mo}_{2} \mathrm{C} / \mathrm{CC}$ and $\mathrm{Pt} / \mathrm{C}+\mathrm{IrO}_{2}$ at $10 \mathrm{~mA} \mathrm{~cm}{ }^{-2}$. (e) Discharge/charge cycling curves $@ 10 \mathrm{~mA} \mathrm{~cm}{ }^{-2}$. (f) Charge-discharge efficiency comparison of the $\mathrm{NiCo}_{2} \mathrm{O}_{4} @ \mathrm{NCD}-\mathrm{Mo}_{2} \mathrm{C} / \mathrm{CC}$ and $\mathrm{Pt} / \mathrm{C}+\mathrm{IrO}_{2}$ based $\mathrm{Zn}$-air battery. 
As a proof-of-concept, a rechargeable $\mathrm{Zn}$-air battery device was made using $\mathrm{NiCo}_{2} \mathrm{O}_{4} @ \mathrm{NCD}-\mathrm{Mo}_{2} \mathrm{C} / \mathrm{CC}$ as the air cathode, as illustrated in Fig. 9a. A mixture of $\mathrm{Pt} / \mathrm{C}+\mathrm{IrO}_{2}(1: 1 \mathrm{wt} \%)$ was also tested for comparison. The open-circuit voltage of $\mathrm{NiCo}_{2} \mathrm{O}_{4} @ \mathrm{NCD}-\mathrm{Mo}_{2} \mathrm{C} / \mathrm{CC}$ driven Zn-air battery is $1.393 \mathrm{~V}$ (Fig. S4). From the charging/discharging polarization curves in Fig. 9a, the $\mathrm{NiCo}_{2} \mathrm{O}_{4} @ \mathrm{NCD}-\mathrm{Mo}_{2} \mathrm{C} / \mathrm{CC}$-based battery exhibited a smaller polarization voltage relative to the noble metal-based battery. Importantly, the peak power density of $\mathrm{NiCo}_{2} \mathrm{O}_{4} @ \mathrm{NCD}-\mathrm{Mo}_{2} \mathrm{C} / \mathrm{CC}$ is $104 \mathrm{~mW} \mathrm{~cm}{ }^{-2}$, larger than that of $\mathrm{Pt} / \mathrm{C}+\mathrm{IrO}_{2}(79 \mathrm{~mW}$ $\mathrm{cm}^{-2}$; Fig. 9b). From the continuous discharge profiles in Fig. 9c, $\mathrm{NiCo}_{2} \mathrm{O}_{4} @ \mathrm{NCD}-\mathrm{Mo}_{2} \mathrm{C} / \mathrm{CC}$ battery showed stable discharging ability. Furthermore, the battery based on $\mathrm{NiCo}_{2} \mathrm{O}_{4} @ \mathrm{NCD}-\mathrm{Mo}_{2} \mathrm{C} / \mathrm{CC}$ delivered a higher specific capacity of $778 \mathrm{mAh} \mathrm{g}^{-1}$ than $\mathrm{Pt} / \mathrm{C}+\mathrm{IrO}_{2}\left(657 \mathrm{mAh} \mathrm{g}^{-1}\right.$; Fig. 9d).

The battery cyclic stability of $\mathrm{NiCo}_{2} \mathrm{O}_{4} @ \mathrm{NCD}-\mathrm{Mo}_{2} \mathrm{C} / \mathrm{CC}$ and $\mathrm{Pt} / \mathrm{C}+\mathrm{IrO}{ }_{2}$ catalysts was measured at $10 \mathrm{~mA} \mathrm{~cm}{ }^{-2}$ (Fig. 9e). After 300 cycles $(10$ min per cycle), it is found that the $\mathrm{NiCo}_{2} \mathrm{O}_{4} @ \mathrm{NCD}-\mathrm{Mo}_{2} \mathrm{C} / \mathrm{CC}$-driven battery delivered a stable voltage compared with the $\mathrm{Pt} / \mathrm{C}+\mathrm{IrO}_{2}$-based battery. Discharge efficiencies of $\mathrm{NiCo}_{2} \mathrm{O}_{4} @ \mathrm{NCD}-\mathrm{Mo}_{2} \mathrm{C} / \mathrm{CC}$ and $\mathrm{Pt} / \mathrm{C}+\mathrm{IrO}_{2}$ based $\mathrm{Zn}$-air battery are shown in the Fig. 9f, for the $\mathrm{NiCo}_{2} \mathrm{O}_{4} @ \mathrm{NCD}-\mathrm{Mo}_{2} \mathrm{C} / \mathrm{CC}$, the discharge efficiency increases from $57.39 \%$ to $58.45 \%$ at the $300^{\text {th }}$ cycle. In contrast, the $\mathrm{Pt} / \mathrm{C}+\mathrm{IrO}_{2}$-driven $\mathrm{Zn}$-air battery showed a decreased efficiency from $56.02 \%$ to $52.74 \%$ discharged for just 220 cycles. These results prove that $\mathrm{NiCo}_{2} \mathrm{O}_{4} @ \mathrm{NCD}-\mathrm{Mo}_{2} \mathrm{C} / \mathrm{CC}$ has promising practical applications in many fields. 


\section{Conclusion}

In summary, needle-forest $\mathrm{NiCo}_{2} \mathrm{O}_{4} @ \mathrm{NDC}-\mathrm{Mo}_{2} \mathrm{C} / \mathrm{CC}$ electrocatalyst are prepared by a facile hydrothermal method. The nitrogen-doped carbon (NDC) greatly improves the electrical conductivity of the hybrid material, boosting formation of plenty of active sites. Under the cooperation between $\mathrm{NiCo}_{2} \mathrm{O}_{4}$ and $\mathrm{NDC}-\mathrm{Mo}_{2} \mathrm{C}$, significant catalysis of HER and OER for water hydrolysis in the alkaline medium is gained. The HER and OER overpotential @ $10 \mathrm{~mA} \mathrm{~cm}{ }^{-2}$ can be low as $120 \mathrm{mV}$ and $220 \mathrm{mV}$, with catalytic activity close to $\mathrm{Pt} / \mathrm{C}$ and $\mathrm{IrO}_{2}$, respectively. Notably, the $\mathrm{NiCo}_{2} \mathrm{O}_{4} @ \mathrm{NDC}-\mathrm{Mo}_{2} \mathrm{C} / \mathrm{CC}$ catalyst exhibits remarkable ORR performances with half wave potential of $0.79 \mathrm{~V}$ in the alkaline electrolyte. Depended on the enhanced conductivity from NDC and the strong mechanical support from CC, $\mathrm{NiCo}_{2} \mathrm{O}_{4} @ \mathrm{NDC}-\mathrm{Mo}_{2} \mathrm{C} / \mathrm{CC}$ shows high stable cycling performances. Meanwhile, $\mathrm{NiCo}_{2} \mathrm{O}_{4} @ \mathrm{NDC}-\mathrm{Mo}_{2} \mathrm{C} / \mathrm{CC}$-based electrolyzer showed good water-splitting performance and the corresponding Zn-air batteries exhibit long cycle life, stability and a large specific capacity. This work provides a facile strategy for preparing cost-effective non-precious-metal double functional electrocatalysts used in the field of water splitting and Zn-air battery.

\section{Declaration}

The authors declare that they have no conflict of interest that could have appeared to influence the work reported in this paper.

\section{Acknowledgements}

This study was funded by the National Natural Science Foundation of China (Grant 
No. 21772152), the Key Research and Development Program of Shaanxi (No. 2021GY-220).

\section{Reference}

[1] Li JM, Kang YM, Liu D, Lei ZQ, Liu P (2020) Nitrogen-Doped Graphitic Carbon-Supported Ultrafine Co Nanoparticles as an Efficient Multifunctional Electrocatalyst for HER and Rechargeable Zn-Air Batteries. ACS Appl Mater Interfaces 12: 5717-5729.

[2] Wang H, Le H-W, Deng Y, Lu Z, Hsu P-C, Liu Y, Lin D, Cui Y (2015) Bifunctional non-noble metal oxide nanoparticle electrocatalysts through lithium-induced conversion for overall water splitting. Nat Commun 6: doi.org/10.1038/ncomms8261.

[3] Hu Q, Li G. M, Li GD, Liu XF, Zhu B, Chai XY, Zhang QL, Liu JH, He CH (2019) Trifunctional Electrocatalysis on Dual-Doped Graphene NanoringsIntegrated Boxes for Efficient Water Splitting and Zn-Air Batteries. Adv Energy Mater 9: 1803867.

[4] Ren J-T, Chen L, Wang Y-S, Tian W-W, Gao L-J, Yuan Z-Y (2020) FeNi Nanoalloys Encapsulated in N-Doped CNTs Tangled with N-Doped Carbon Nanosheets as Efficient Multifunctional Catalysts for Overall Water Splitting and Rechargeable Zn-Air Batteries. ACS Sustainable Chem Eng 8: 223-237.

[5] Jiang Y, Geng Z, Sun Y, Wang X, Huang K, Cong Y, Shi F, Wang Y, Zhang W, Feng S (2020) Highly Efficient B-Site Exsolution Assisted by Co Doping in 
Lanthanum Ferrite toward High-Performance Electrocatalysts for Oxygen Evolution and Oxygen Reduction. ACS Sustainable Chem Eng 8: 302-310.

[6] Kanan MW, Nocera DG (2008) In situ formation of an oxygen-evolving catalyst in neutral water containing phosphate and $\mathrm{Co}^{2+}$. Science 321: 1072-1075.

[7] Suntivich J, May KJ, Gasteiger HA, Goodenough JB, Yang S-H (2011) A perovskite oxide optimized for oxygen evolution catalysis from molecular orbital principles. Science 334: 1383-1385.

[8] Huang J, Chen J, Yao T, He J, Jiang S, Sun Z, Liu Q, Cheng W, Hu F, Jiang Y, Pan Z, Wei S (2015) CoOOH nanosheets with high mass activity for water oxidation. Angew Chem Int Ed 54: 8722-8727.

[9] Jaramillo TF, Jorgensen KP, Bonde J, Nielsen JH, Horch S, Chorkendorff I (2007) Identification of active edge sites for electrochemical $\mathrm{H}_{2}$ evolution from $\mathrm{MoS}_{2}$ nanocatalysts. Science 317: 100-102.

[10] Yan X, Tian L, Li K, Atkins S, Zhao H, Murowchick J, Liu L, Chen X (2016) $\mathrm{FeNi}_{3} / \mathrm{NiFeO}_{\mathrm{x}}$ nanohybrids as highly efficient bifunctional electrocatalysts for overall water splitting. Adv Mater Interfaces 3: doi.org/10.1002/admi.201600368.

[11]Tian L, Yan X, Chen X (2016) Electrochemical activity of iron phosphide nanoparticlesin hydrogen evolution reaction. ACS Catal 6: 5441-5448.

[12]Tian L, Yan X, Chen X, Liu L, Chen X (2016) One-pot, large-scale, facile synthesis of $\mathrm{Co}_{\mathrm{x}} \mathrm{P}$ nanocatalysts for electrochemical hydrogen evolution. J Mater Chem A 4: 13011-13016.

[13] Yan X, Tian L, He M, Chen X (2015) Three-dimensional crystalline/amorphous 
$\mathrm{Co} / \mathrm{Co}_{3} \mathrm{O}_{4}$ core/shell nanosheets as efficient electrocatalysts for the hydrogen evolution reaction. Nano Lett 15: 6015-6021.

[14] Yan X, Li K, Lyu L, Song F, He J, Niu D, Liu L, Hu X, Chen X (2016) From water oxidation to reduction: transformation from $\mathrm{NixCo}_{3-\mathrm{x}} \mathrm{O}_{4}$ nanowires to $\mathrm{NiCo} / \mathrm{NiCoO}_{x}$ heterostructures. ACS Appl Mater Inter 8: 3208-3214.

[15]Xiao X, Huang D, Jiang X, Lv X, Li M, Gao L, Liu S, Wang M, Shen Y (2018) Engineering $\mathrm{NiS} / \mathrm{Ni}_{2} \mathrm{P}$ heterostructures for efficient electrocatalytic water splitting. ACS Appl Mater Inter 10: 4689-4696.

[16]Lv F, Feng J, Wang K, Dou Z, Zhang W, Zhou J, Yang C, Luo M, Yang Y, Li Y, Gao P, Guo S (2018) Iridium-tungsten alloy nanodendrites as $\mathrm{pH}$-universal water-splitting electrocatalysts. ACS Cent Sci 4: 1244-1252.

[17]Bai JM, Meng T, Guo DL, Wang SG, Mao BG, Cao MH (2018) Co9 $\mathrm{S}_{8} @ \mathrm{MoS}_{2}$ Core-Shell Heterostructures as Trifunctional Electrocatalysts for Overall Water Splitting and Zn-Air Batteries. ACS Appl Mater Interfaces 10: 1678-1689.

[18]Xu L, Jiang Q, Xiao Z, Li X, Huo J, Wang S, Dai L (2016) Plasma-engraved $\mathrm{Co}_{3} \mathrm{O}_{4}$ nanosheets with oxygen vacancies and high surface area for the oxygen evolution reaction. Angew Chem Int Ed 55: 5277-5281.

[19] Wang H-Y, Hsu Y-Y, Chen R, Chan T-S, Chen H, Liu B (2015) $\mathrm{Ni}^{3+}$-induced formation of active $\mathrm{NiOOH}$ on the spinel $\mathrm{Ni}-\mathrm{Co}$ oxide surface for efficient oxygen evolution reaction. Adv Energy Mater 5: doi.org/10.1002/aenm.201500091.

[20] Song F, Hu X (2014) Ultrathin cobalt-manganese layered double hydroxide is an 
efficient oxygen evolution catalyst. J Am Chem Soc 136: 16481-16484.

[21]Chen S, Qiao S-Z (2013) Hierarchically porous nitrogen-doped graphene- $\mathrm{NiCo}_{2} \mathrm{O}_{4}$ hybrid paper as an advanced electrocatalytic water-splitting material. ACS Nano 7: 10190-10196.

[22]Xiao X, Hua XY, Liang Y, Zhang GL, Wang XY, Yan YC, Li XH, Yan GC, Wang JX (2020) Anchoring $\mathrm{NiCo}_{2} \mathrm{O}_{4}$ nanowhiskers in biomass-derived porous carbon as superior oxygen electrocatalyst for rechargeable Zn-air battery. J Power Sources 476: 228684.

[23]Xiao X, Li XH, Wang JX, Yan GC, Wang ZX, Guo HJ, Liu Y (2020) Robust assembly of urchin-like $\mathrm{NiCo}_{2} \mathrm{O}_{4} / \mathrm{CNTs}$ architecture as bifunctional electrocatalyst in Zn-Air batteries. Ceram Int 46: 6262-6269.

[24] She ZW, Kibsgaard J, Dickens CF, Chorkendorff IB, Norskov JK, Jaramillo TF (2017) Combining theory and experiment in electrocatalysis: Insights into materials design. Science 355: doi.org/10.1126/science.aad4998.

[25]Zhang X, Li J, Yang Y, Zhang S, Zhu H, Zhu X, Xing H, Zhang Y, Huang B, Guo S, Wang E (2018) $\mathrm{Co}_{3} \mathrm{O}_{4} / \mathrm{Fe}_{0.33} \mathrm{Co}_{0.66} \mathrm{P}$ interface nanowire for enhancing water oxidation catalysis at high current density. Adv Mater 30: doi.org10.1002/adma.201803551.

[26] Wan C, Regmi YN, Leonard BM (2014) Multiple phases of molybdenum carbide as electrocatalysts for the hydrogen evolution reaction. Angew Chem Int Ed 53: $6407-6410$.

[27] Ma Y, Guan G, Hao X, Cao J, Abudula A (2016) Molybdenum carbide as 
alternative catalyst for hydrogen production-A review. Renew Sustain Energy Rev 75: 1101-1129.

[28] Yang W, Gao Z, Ma J, Zhang X, Wang J, Liu J (2014) Hierarchical $\mathrm{NiCo}_{2} \mathrm{O}_{4} @ \mathrm{NiO}$ core-shell heterostructured nanowire arrays on carbon cloth for a high-performance flexible all-solid-state electrochemical capacitor. J Mater Chem A 2: $1448-1457$.

[29] Chen W-F, Wang C-H, Sasai K, Marinkovic N, Xu W, Muckerman JT, Zhu Y, Adzic RR (2013) Highly active and durable nanostructured molybdenum carbide electrocatalysts for hydrogen production. Energy Environ Sci 6: 943-951.

[30]Liu X, Zhang L, Lan X, Hu X (2018) Paragenesis of $\mathrm{Mo}_{2} \mathrm{C}$ nanocrystals in mesoporous carbon nanofibers for electrocatalytic hydrogen evolution. Electrochim Acta 274: 23-30.

[31] Merabet L, Rida K, Boukmouche N (2018) Sol-gel synthesis, characterization, and supercapacitor applications of $\mathrm{MCo}_{2} \mathrm{O}_{4}(\mathrm{M}=\mathrm{Ni}, \mathrm{Mn}, \mathrm{Cu}, \mathrm{Zn})$ cobaltite spinels. Ceram Int 44: 11265-11273.

[32] Wu C, Li J (2017) Unique hierarchical $\mathrm{Mo}_{2} \mathrm{C} / \mathrm{C}$ nanosheet hybrids as active electrocatalyst for hydrogen evolution reaction. ACS Appl Mater Inter 9: $41314-41322$.

[33]Dong Y, Liu M, Liu Y, Wang S, Li J (2015) Molybdenum-doped mesoporous carbon/graphene composites as an efficient electrocatalyst for oxygen reduction reaction. J Mater Chem A 3: 19969-19973.

[34]Tang C, Zhang H, Jiao D, Hu R, Liu Z (2019) Hierarchical C-doped CuO 
nanorods on carbon cloth as flexible binder-free anode for lithium storage. Mater Design 162: 52-59.

[35] Wang S, Zhang K, Wang Q, Fan Y, Shen J, Li L, Yang L, Zhang W (2019) Graphene quantum dot-assisted preparation of water-borne reduced graphene oxide/polyaniline: From composite powder to layer-by-layer self-assembly film and performance enhancement. Electrochim Acta 295: 29-38.

[36]Zhang Q, Deng Y, Hu Z, Liu Y, Yao M, Liu P (2014) Seaurchin-like hierarchical $\mathrm{NiCo}_{2} \mathrm{O}_{4} @ \mathrm{NiMoO}_{4}$ core/shell nanomaterials for high performance supercapacitor. Phys Chem Chem Phys 16: 23451-23460.

[37]Fan W, Li H, Zhao F, Xiao X, Huang Y, Ji H, Tong Y (2016) Boosting the photocatalytic performance of (001) BiOI: enhancing donor density and separation efficiency of photogenerated electrons and holes. Chem Commun 52: $5316-5319$.

[38]Zhang B, Wang L, Zhang Y, Ding Y, Bi Y (2018) Ultrathin FeOOH nanolayers with abundant oxygen vacancies on $\mathrm{BiVO}_{4}$ photoanodes for efficient water oxidation. Angew Chem Int Ed 57: 2248-2252.

[39] Mahala C, Basu M (2017) Nanosheets of $\mathrm{NiCo}_{2} \mathrm{O}_{4} / \mathrm{NiO}$ as Efficient and Stable Electrocatalyst for Oxygen Evolution Reaction. ACS Omega 2: 7559-7567.

[40] Yan J, Fan Z, Sun W, Ning G, Wei T, Zhang Q, Zhang R, Zhi L, Wei F (2012) Advanced Asymmetric supercapacitors based on $\mathrm{Ni}(\mathrm{OH})_{2} / \mathrm{Graphene}$ and porous graphene electrodes with high energy density. Adv Funct Mater 22: 2632-2641.

[41] Yang Y, Zeng D, Shao S, Hao S, Zhu G, Liu B (2019) Construction of core-shell 
mesoporous carbon nanofiber@nickel cobaltite nanostructures as highly efficient catalysts towards 4-nitrophenol reduction. J Colloid Inter Sci 538: 377-386.

[42] Shen J, Wang Q, Zhang K, Wang S, Li L, Dong S, Zhao S, Chen J, Sun R, Wang Y, Jian Z, Zhang W (2019) Flexible carbon cloth based solid-state supercapacitor from hierarchical holothurian-morphological $\quad \mathrm{NiCo}_{2} \mathrm{O}_{4} @ \mathrm{NiMoO}_{4} / \mathrm{PANI}$. Electrochim Acta 320: doi.org/10.1016/j.electacta.2019.134578.

[43]Zhang M, Liu W, Han R, Xu J, Sun Z, Liu J, Wu Y (2019) Facile construction of $3 \mathrm{D}$ packing porous flower-like $\mathrm{NiCo}_{2} \mathrm{O}_{4} @ \mathrm{NiMoO}_{4} / \mathrm{rGO}$ hybrids as high-performance supercapacitors with large areal capacitance. Energy Technol 7: doi.org/10.1002/ente.201800940.

[44]Li M, Wang H, Zhu Y, Tian D, Wang C, Lu X (2019) Mo/Mo ${ }_{2} \mathrm{C}$ encapsulated in nitrogen-doped carbon nanofibers as efficiently integrated heterojunction electrocatalysts for hydrogen evolution reaction in wide $\mathrm{pH}$ range. Appl Surf Sci 496: doi.org/10.1016/j.apsusc.2019.143672.

[45]Chaitoglou S, Giannakopoulou T, Papanastasiou G, Tsoutsou D, Vavouliotis A, Trapalis C, Dimoulas A (2020) Cu vapor-assisted formation of nanostructured $\mathrm{Mo}_{2} \mathrm{C}$ electrocatalysts via direct chemical conversion of Mo surface for efficient hydrogen evolution reaction applications. Appl Surf Sci 510: doi.org/10.1016/j.apsusc.2020.145516.

[46] Yan Q, Yang X, Wei T, Zhou C, Wu W, Zeng L, Zhu R, Cheng K, Ye K, Zhu K, Yan J, Cao D, Wang G (2020) Porous $\beta-\mathrm{Mo}_{2} \mathrm{C}$ nanoparticle clusters supported on walnut shell powders derived carbon matrix for hydrogen evolution reaction. J 
Colloid Interf Sci 563: 104-111.

[47] Mondal A, Sinha K, Paul A, Srivastava DN, Panda AB (2019) Large scale synthesis of $\mathrm{Mo}_{2} \mathrm{C}$ nanoparticle incorporated carbon nanosheet $\left(\mathrm{Mo}_{2} \mathrm{C}-\mathrm{C}\right)$ for enhanced hydrogen evolution reaction. Int $J$ Hydrogen Energ doi.org/10.1016/j.ijhydene.2019.09.051.

[48]Lan K, Gong L, Yang M, Huang X, Jiang P, Wang K, Ma L, Li R (2019) Nitrogen and phosphorus dual-doping carbon shells encapsulating ultrafine $\mathrm{Mo}_{2} \mathrm{C}$ particles as electrocatalyst for hydrogen evolution. J Colloid Interf Sci 553: 148-155.

[49]Chen J, Ling Y, Lu Z, Huai X, Qin F, Zhang Z (2019) Sandwich-like $\mathrm{NiO}_{x} / \mathrm{NiCo}_{2} \mathrm{O}_{4} / \mathrm{Co}_{3} \mathrm{O}_{4}$ nanoflakes enable efficient oxygen evolution electrocatalysis. Electrochim Acta 322: doi.org/10.1016/j.electacta.2019.134753.

[50]Zhao R, Cui D, Dai J, Xiang J, Wu F (2020) Morphology controllable $\mathrm{NiCo}_{2} \mathrm{O}_{4}$ nanostructure for excellent energy storage device and overall water splitting. Sustain Mater Technol 24: doi.org/10.1016/j.susmat.2020.e00151.

[51] Sun S, Jin X, Cong B, Zhou X, Hong W, Chen G (2019) Construction of porous nanoscale $\mathrm{NiO} / \mathrm{NiCO}_{2} \mathrm{O}_{4}$ heterostructure for highly enhanced electrocatalytic oxygen evolution activity. J Catal 379: 1-9.

[52]Zhang Y, Yang M, Jiang X, Lu W, Xing Y (2019) Self-supported hierarchical $\mathrm{CoFe}-\mathrm{LDH} / \mathrm{NiCo}_{2} \mathrm{O}_{4} / \mathrm{NF}$ core-shell nanowire arrays as an effective electrocatalyst for oxygen evolution reaction. J Alloy Compd 818: doi.org/10.1016/j.jallcom.2019.153345.

[53] Yan K-L, Shang X, Gao W-K, Dong B, Li X, Chi J-Q, Liu Y-R, Chai Y-M, Liu 
C-G (2017) Ternary $\mathrm{MnO}_{2} / \mathrm{NiCo}_{2} \mathrm{O}_{4} / \mathrm{NF}$ with hierarchical structure and synergistic interaction as efficient electrocatalysts for oxygen evolution reaction. J Alloy Compd 719: 314-321.

[54] Wu D, Huang H, Zhou Y, Liu Y, Kang Z (2019) N doped carbon dots modified needle-like $\mathrm{NiCo}_{2} \mathrm{O}_{4}$ supported on graphene as efficient dual-functional electrocatalyst for oxygen reduction and evolution reactions. J Electroanal Chem 855: doi.org/10.1016/j.jelechem.2019.113617.

[55]Béjar J, Álvarez-Contreras L, NoéArjona JL, Arriaga LG (2019) Electrocatalytic evaluation of $\mathrm{Co}_{3} \mathrm{O}_{4}$ and $\mathrm{NiCo}_{2} \mathrm{O}_{4}$ rosettes-like hierarchical spinel as bifunctional materials for oxygen evolution (OER) and reduction (ORR) reactions in alkaline media. J Electroanal Chem 847: doi.org/10.1016/j.jelechem.2019.113190.

[56] Shi R, Wang J, Wang Z, Li T, Song YF (2019) Unique NiFe-NiCoO 2 hollow polyhedron as bifunctional electrocatalysts for water splitting. J Energy Chem 33: $74-80$.

[57]Wang HQ, Wang XQ, Zheng BJ, Yang DX, Zhang WL, Chen YF (2019) Self-assembled $\mathrm{Ni}_{2} \mathrm{P} / \mathrm{FeP}$ heterostructural nanoparticles embedded in $\mathrm{N}$-doped graphene nanosheets as highly efficient and stable multifunctional electrocatalyst for water splitting. Electrochim Acta 318: 449-459.

[58]Sang Y, Cao X, Wang L, Ding G, Wang Y, Yu D, Hao Y, Li L, Peng S (2020) Facile synthesis of three-dimensional spherical $\mathrm{Ni}(\mathrm{OH})_{2} / \mathrm{NiCo}_{2} \mathrm{O}_{4}$ heterojunctions as efficient bifunctional electrocatalysts for water splitting. Int J Hydrogen Energ 45: 30601-30610. 
[59] Zhang Y, Shao Q, Long S, Huang XQ (2018) Cobalt-molybdenum nanosheet arrays as highly efficient and stable earth-abundant electrocatalysts for overall water splitting. Nano Energy 45: 448-455. 


\section{HIGHLIGHTS}

- Catalyst of nanoneedle-forest $\mathrm{NiCo}_{2} \mathrm{O}_{4} @ \mathrm{NDC}-\mathrm{Mo}_{2} \mathrm{C} / \mathrm{CC}$ is prepared.

- The catalyst shows more oxygen vacancies and enhanced conductivity.

- The multifunctional catalyst presents improved OER, HER and ORR performance. 
GRAPHICAL ABSTRACT

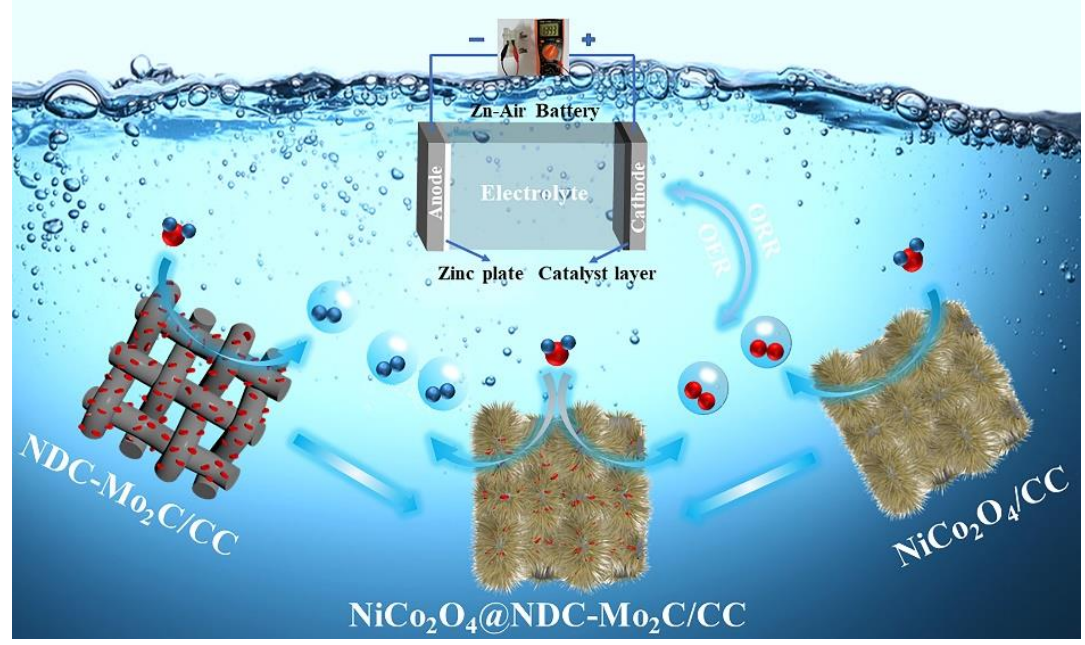


Figures
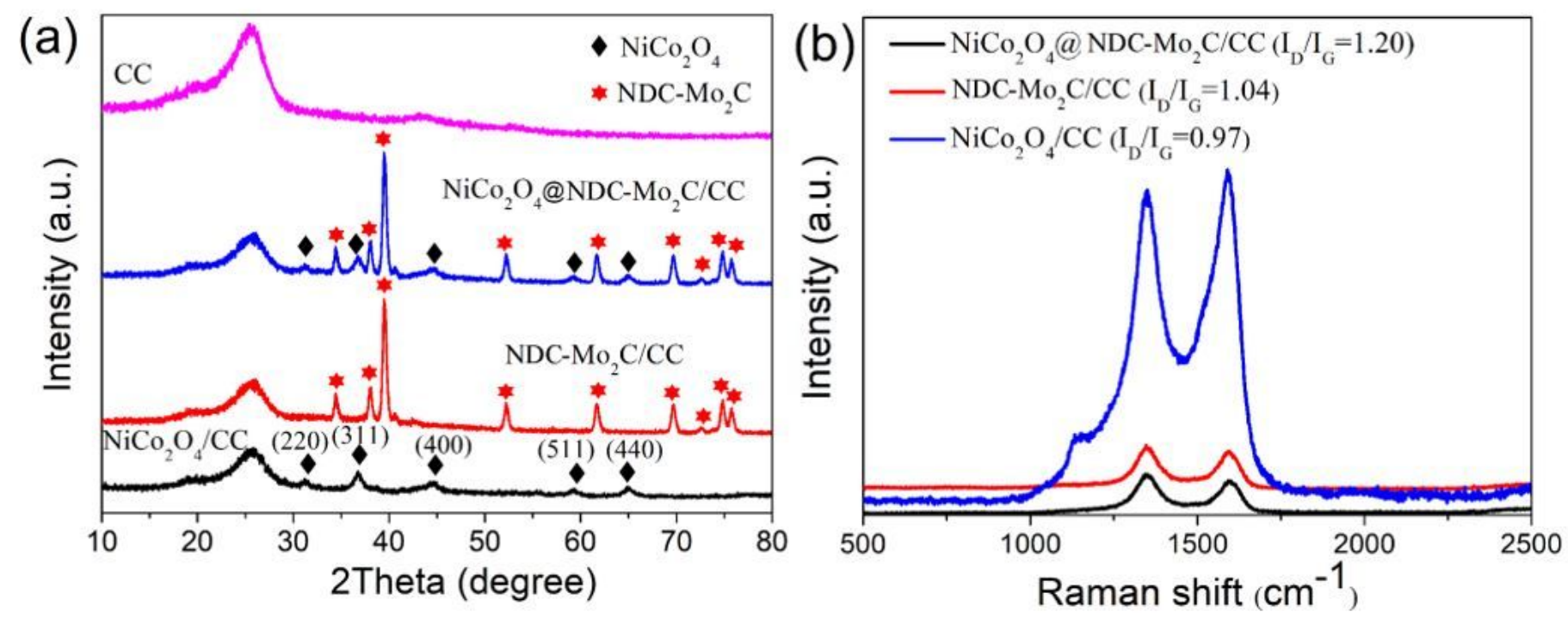

Figure 1

XRD (a) and Raman patterns (b) of CC, NiCo2O4@NDC-Mo2C/CC, NDC-Mo2C/CC and NiCo2O4/CC. 

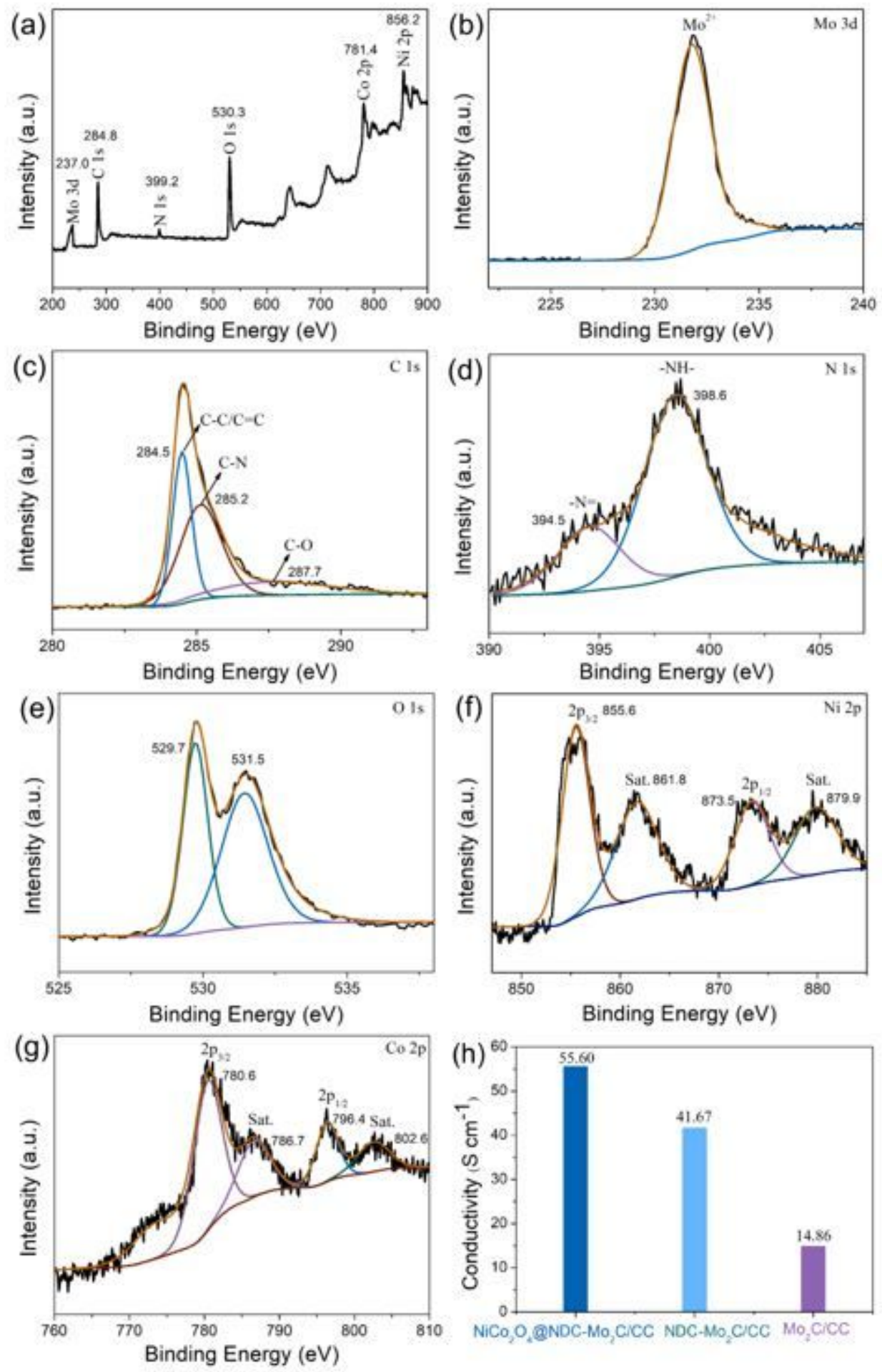

Figure 2

XPS spectra of NiCo204@NDC-Mo2C/CC: survey scan spectrum (a), Mo 3d spectrum (b), C 1s spectrum (c), N 1s spectrum (d), 0 1s spectrum (e), Ni 2p spectrum (f) and Co 2p spectrum (g). the conductivity of catalysts $(\mathrm{h})$. 


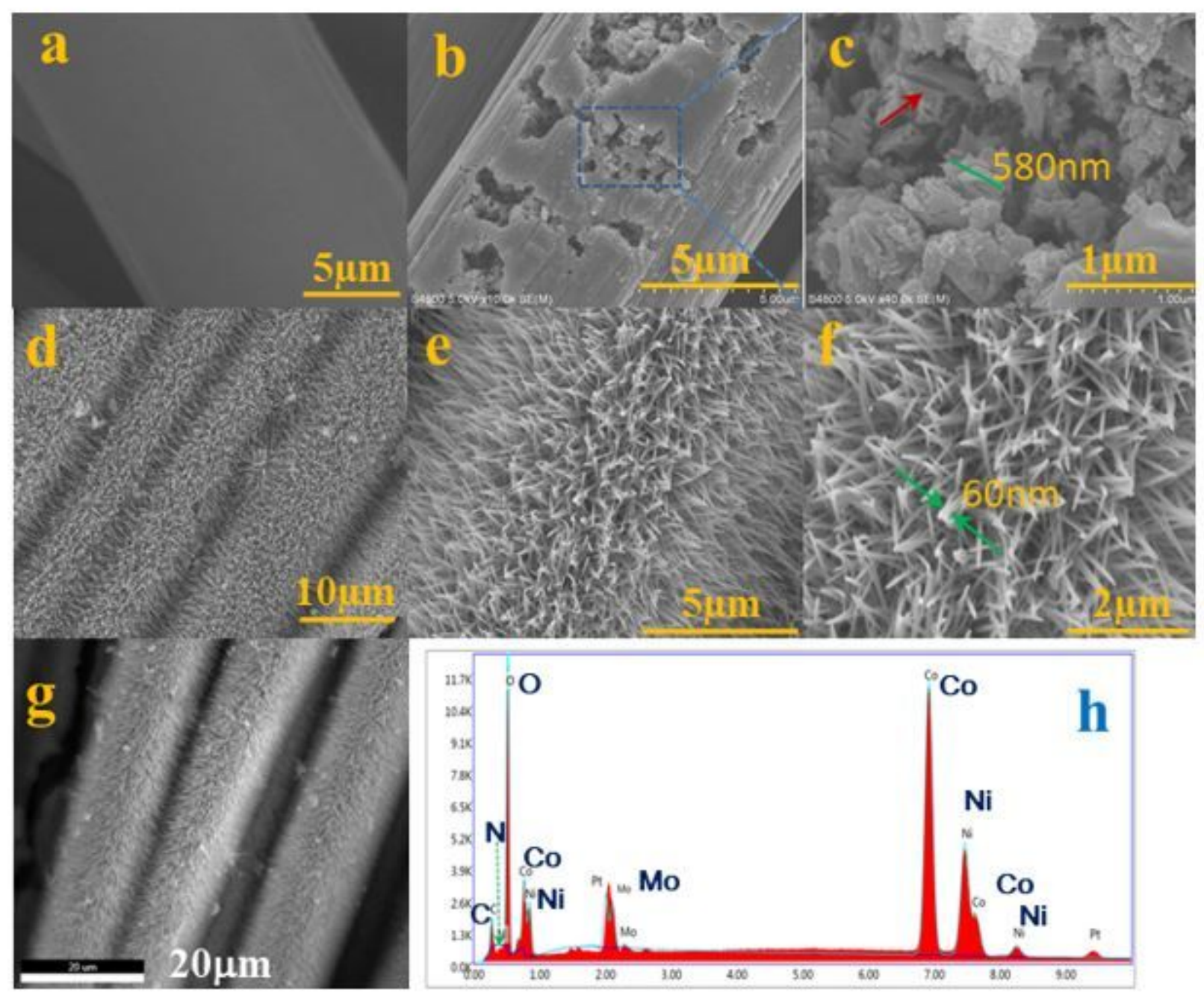

Figure 3

SEM images of CC (a), NDC-Mo2C/CC (b, c), NiCo204@NDC-Mo2C/CC (d, e, f and g). EDS spectrum of NiCo204@NDC-Mo2C/CC (h). 

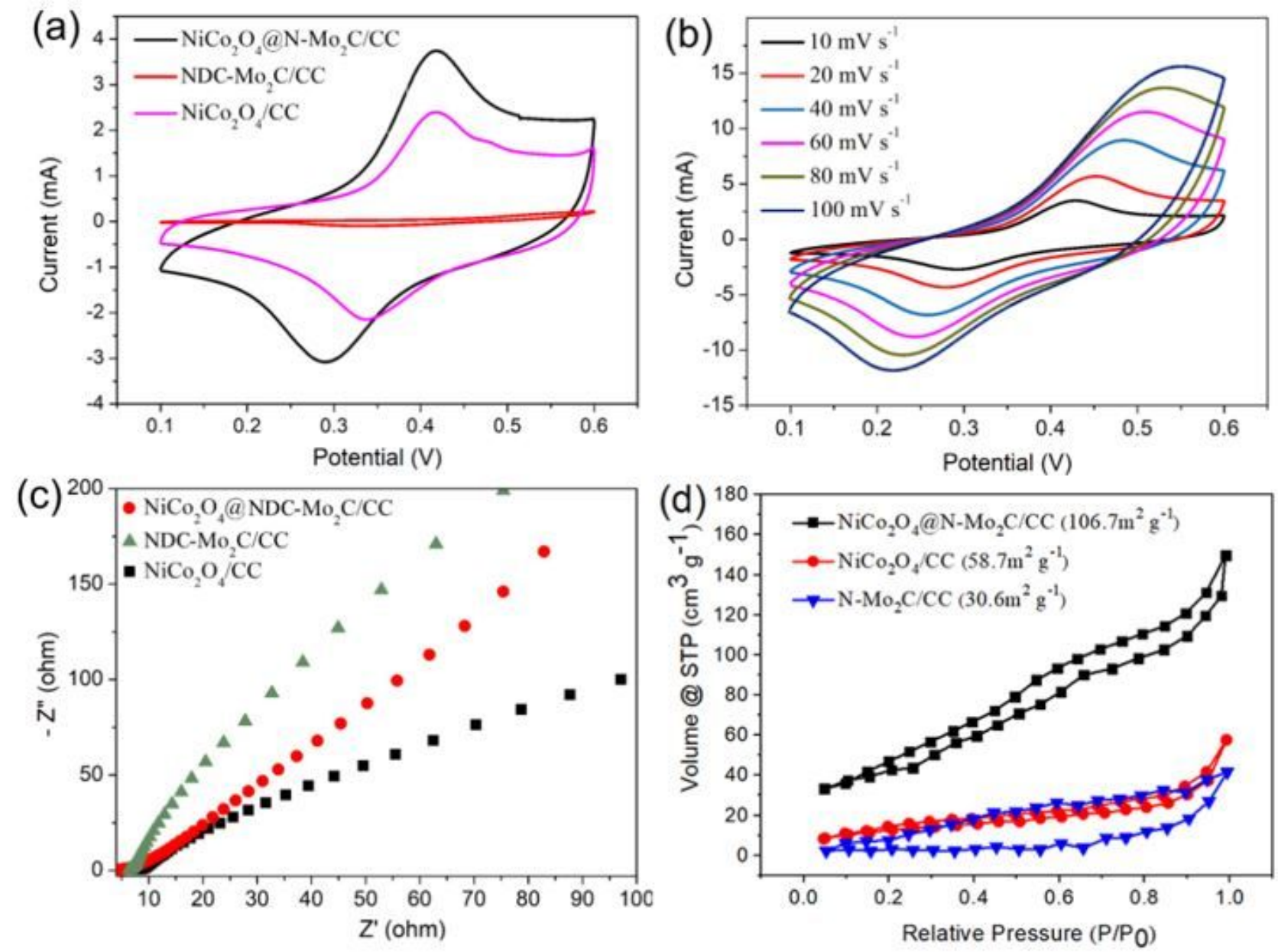

Figure 4

(a) CV curves of NiCo204@NDC-Mo2C/CC. (b) CV plots of NiCo204@NDC-Mo2C/CC NiCo204@NDC$\mathrm{Mo2C} / \mathrm{CC}$ at different scanning rate. (c) Nyquist plots of the NiCo2O4@NDC-Mo2C/CC, NiCo204/CC and NDC-Mo2C/CC. (d) BET nitrogen adsorption and desorption isotherms of the NiCo2O4@NDC-Mo2C/CC, $\mathrm{NiCo} 204 / \mathrm{CC}$ and NDC-Mo2C/CC. 

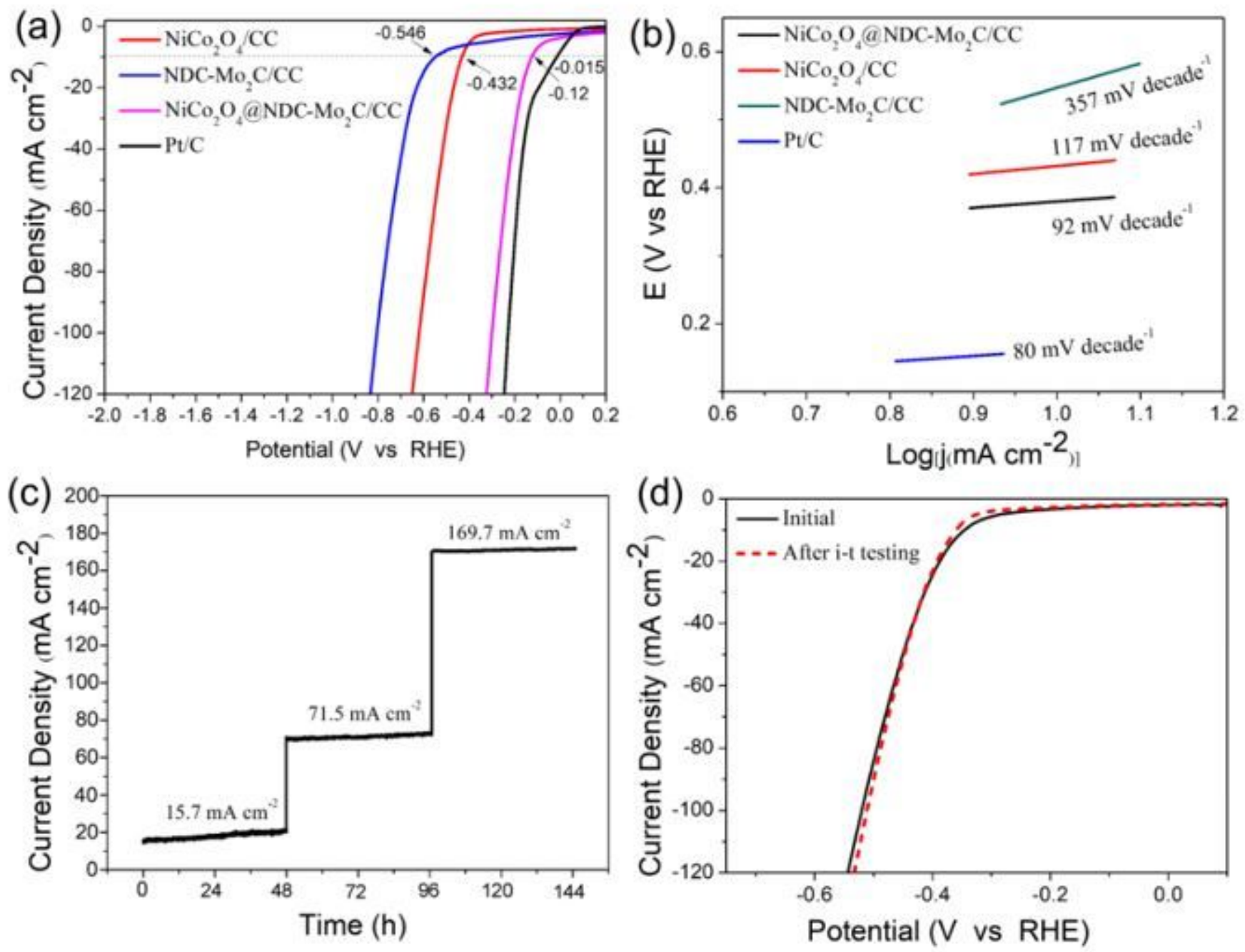

Figure 5

(a) HER polarization curves of NiCo2O4@NDC-Mo2C/CC in $1 \mathrm{M} \mathrm{KOH}$ electrolytes at $1 \mathrm{mV} \mathrm{s}-1$, along with plots of NiCo204/CC, NDC-Mo2C/CC and Pt/C for comparison. (b) Corresponding Tafel plots. (c) The i-t curve of NiCo204@NDC-Mo2C/CC at -1.3,-1.4 and -1.5 V. (d) LSV curves of NiCo204@NDC-Mo2C/CC before and after i-t test. 
(a)
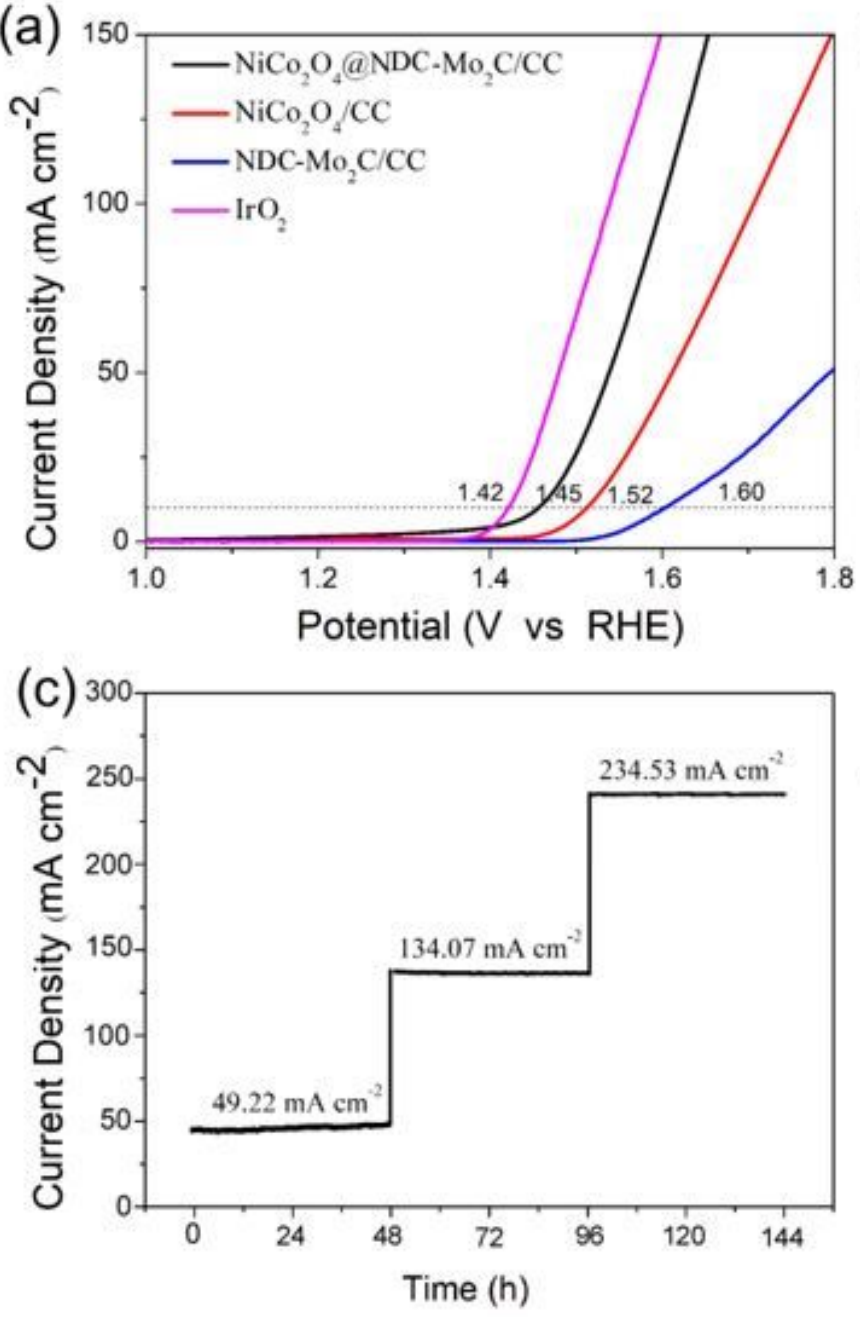

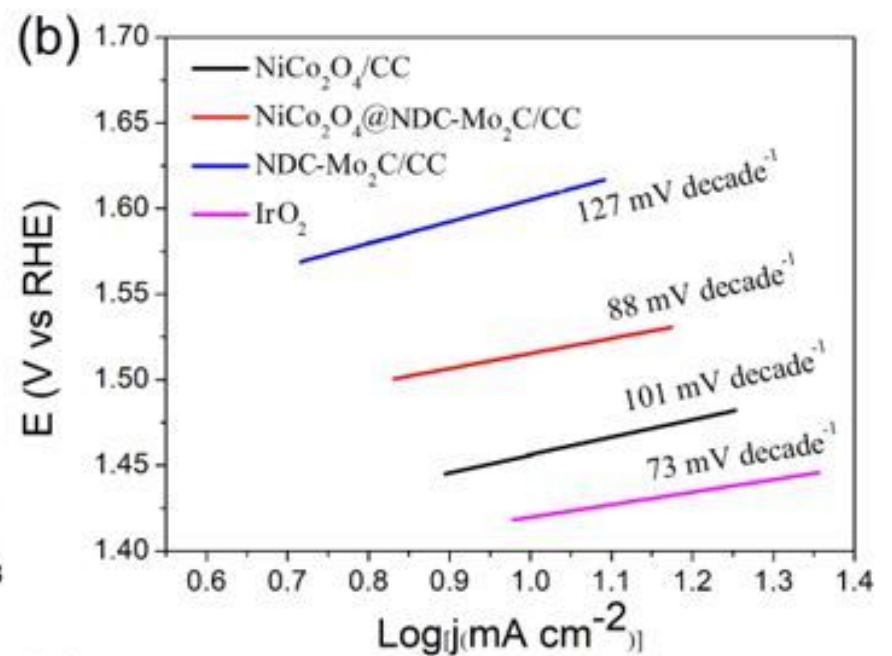

(d)

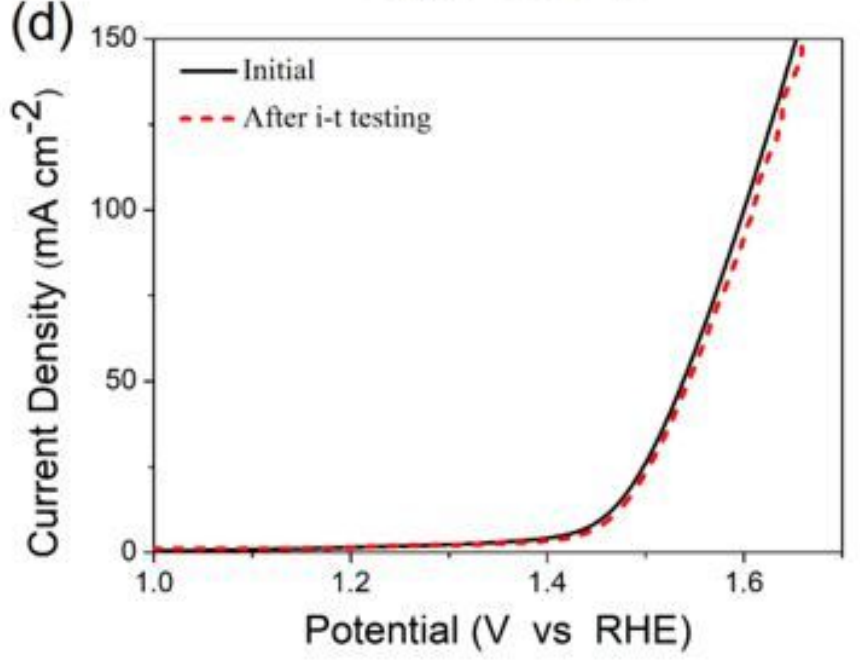

Figure 6

(a) OER polarization curves of NiCo204@NDC-Mo2C/CC in $1 \mathrm{M} \mathrm{KOH}$ electrolytes at $1 \mathrm{mV} \mathrm{s}-1$, along with plots of NiCo204/CC, NDC-Mo2C/CC and Pt/C for comparison. (b) Corresponding Tafel plots. (c) The i-t curve of NiCo204@NDC-Mo2C/CC at 0.7, 0.8 and 0.9 V. (d) LSV curves of NiCo2O4@NDC-Mo2C/CC before and after i-t test. 

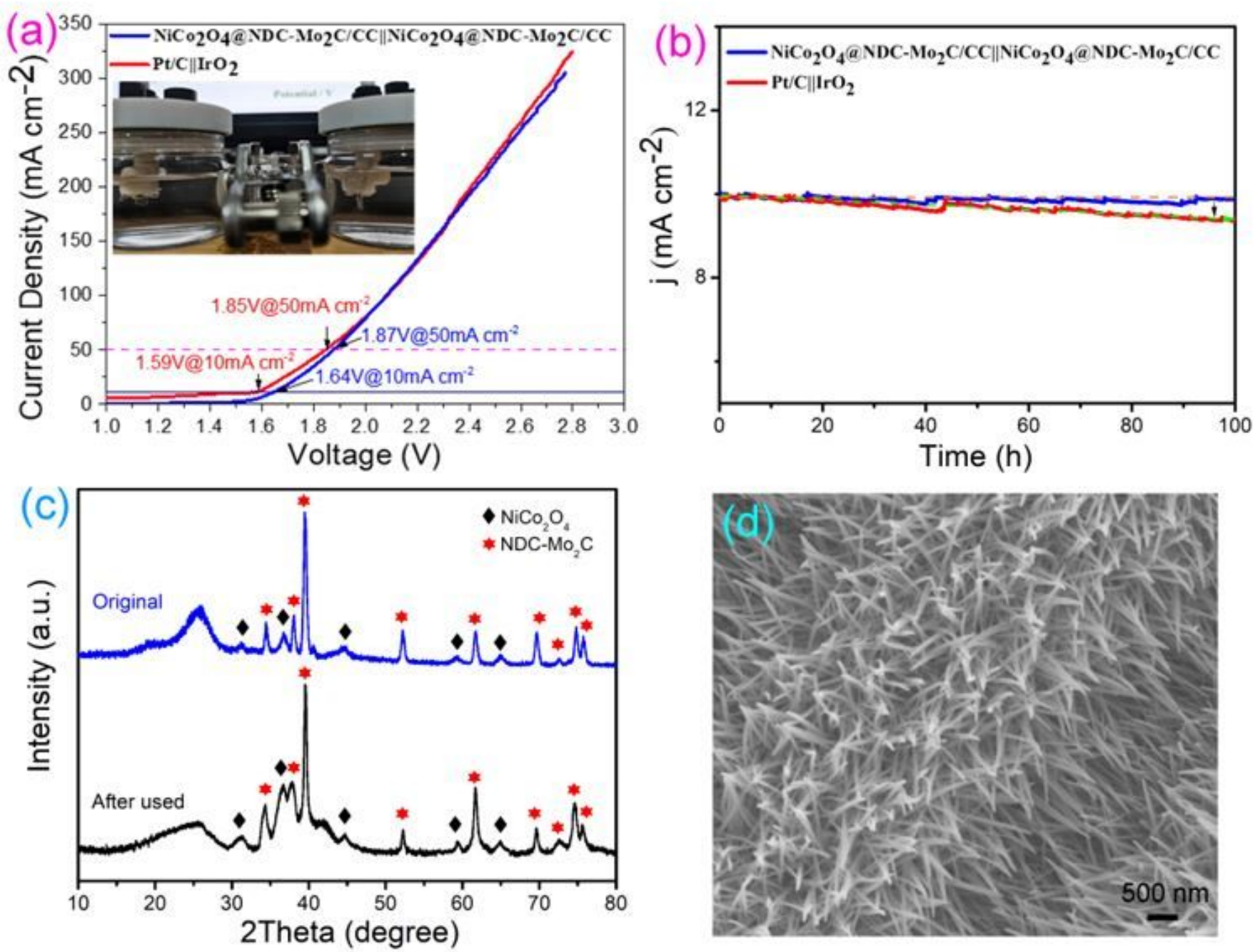

\section{Figure 7}

(a) LSV plot of NiCo2O4@NCD-Mo2C/CC and Pt/C |IrO2 for overall water splitting in $1.0 \mathrm{M} \mathrm{KOH}$ electrolytes. Inset shows the hydrogen and oxygen gas bubbles released from the splitter cell. (b) Longterm stability of NiCo2O4@NCD-Mo2C/CC and Pt/C+lrO2 at 10 mA cm-2. (c) XRD patterns of NiCo204@NCD-Mo2C/CC before and after overall water splitting. (d) SEM image of NiCo204@NCD$\mathrm{Mo} 2 \mathrm{C} / \mathrm{CC}$ after overall water splitting. 

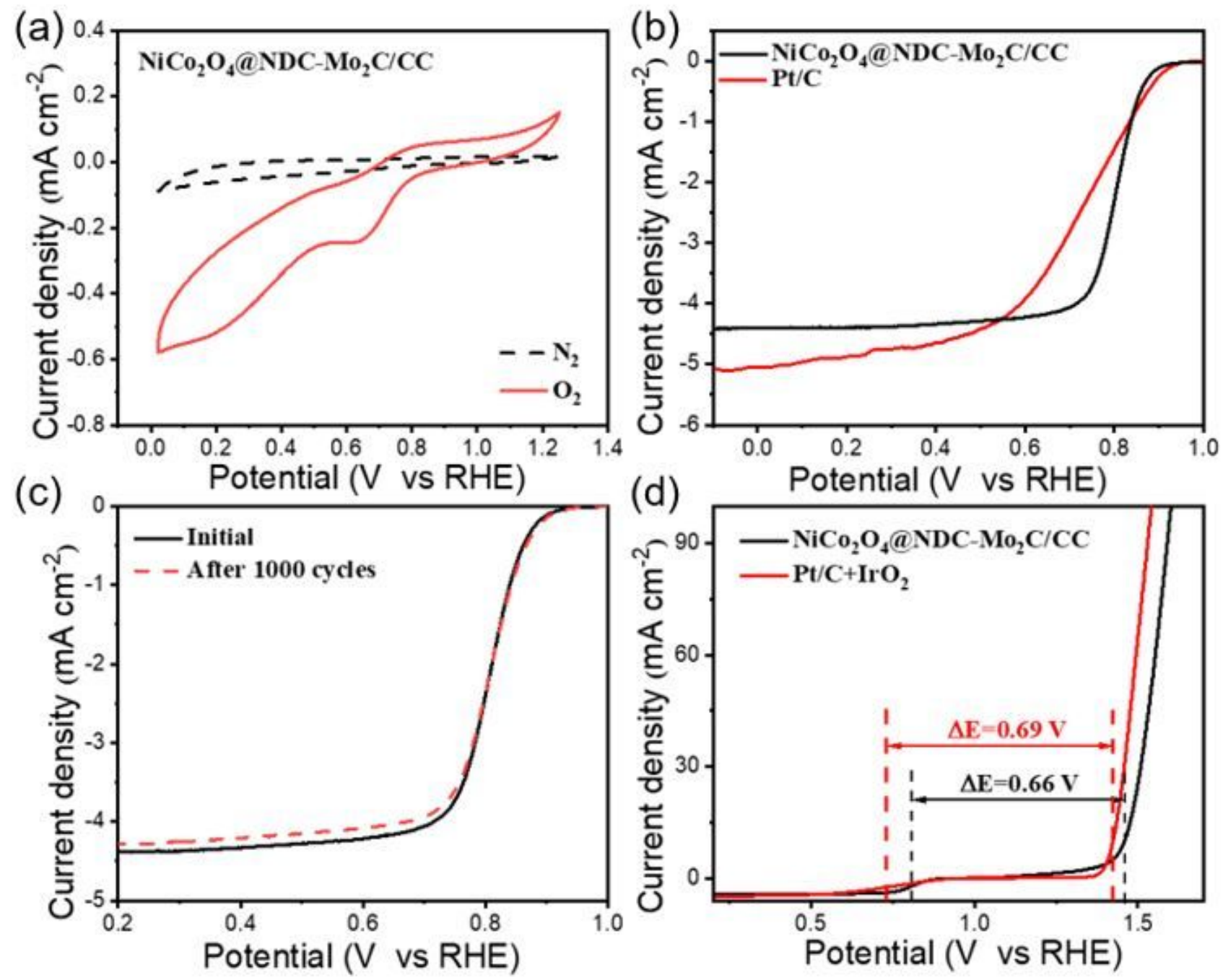

Figure 8

(a) CVs of NiCo2O4@NCD-Mo2C/CC in N2/O2-saturated 0.1 M KOH solution. (b) LSV curves of NiCo204@NCD-Mo2C/CC and Pt/C. (c) LSV curves of NiCo2O4@NCD-Mo2C/CC collected before and after 1000 CV cycles. (d) Combined ORR/OER LSV profiles of NiCo2O4@NCD-Mo2C/CC and Pt/C+IrO2. 

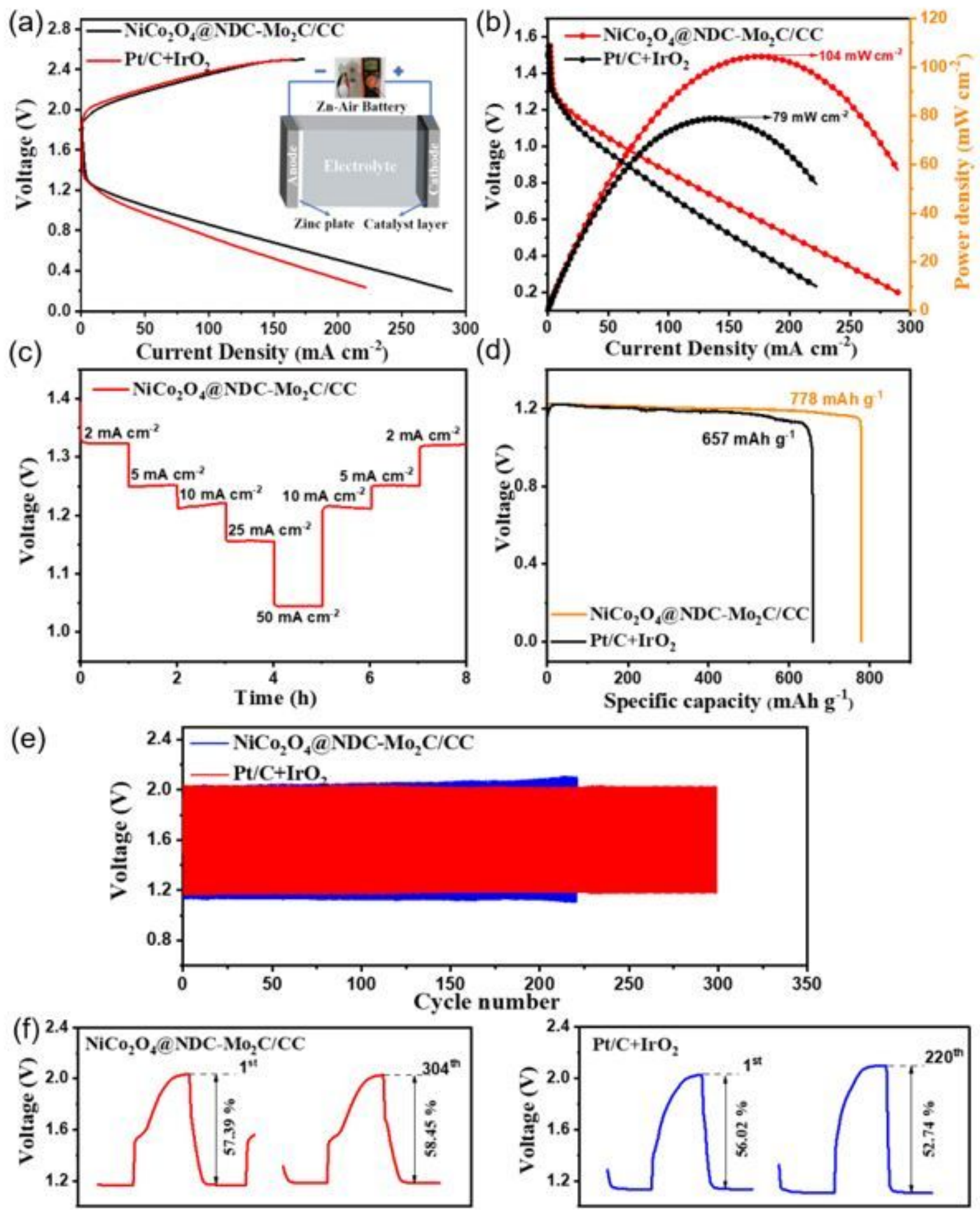

\section{Figure 9}

(a) Charging/discharging polarization curves. Inset in (a) shows the structure of the assembled Zn-air battery. (b) Polarization and corresponding power density profiles. (c) Discharge polarization plots at different current densities. (d) Discharge polarization curves of NiCo204@NCD-Mo2C/CC and Pt/C+IrO2 at $10 \mathrm{~mA} \mathrm{~cm}-2$. (e) Discharge/charge cycling curves @10 mA cm-2. (f) Charge-discharge efficiency comparison of the NiCo2O4@NCD-Mo2C/CC and Pt/C+IrO2 based Zn-air battery. 


\section{Supplementary Files}

This is a list of supplementary files associated with this preprint. Click to download.

- S1.jpg

- SupplementaryMaterial.docx 